\title{
Assessing Student Achievement of Learning Outcomes Through Academic Service-Learning: A Constructive Alignment Study
}

\author{
Christine M. Angel \\ St. John's University
}

The purpose of this study was to determine if academic service-learning (AS-L) assessment activities are properly aligned with intended student learning outcomes (SLOS) and curriculum standards through the analysis of student post-reflections within one required online graduate course. Four coders analyzed postreflections from 77 students over a five-year period. The first goal was to determine the degree of alignment among assessment activities, SLOs, and curriculum standards. The second goal was to determine if students demonstrated differences in achievement when participating in online versus onsite AS-L projects. Results were mixed when determining the degree of alignment among assessments, SLOs, and curriculum standards. Students demonstrated comparable levels of achievement in learning outcomes when participating in both forms of AS-L. Implications of this study indicate that continuous self-assessment in aligning academic service-learning assessment activities to student learning outcomes and curriculum standards is necessary for successful demonstration of student achievement within today's standards-based curriculum of higher education.

Keywords: outcomes based assessment, online learning, alignment, academic service-learning assessment activities, higher education, standards-based curriculum, student learning outcomes, accreditation

\section{INTRODUCTION}

The academic service-learning (AS-L) pedagogy is a valuable tool for library and information studies (LIS) faculty members teaching within the online environment because it enables students to apply knowledge learned within the classroom to the real-world environment (Ball \& Schilling, 2006; Ball, 2008; Bettencourt, 2015; Bossaller, 2016; Dewey, 1938; Hart, 2015; Kolb, 1984; Tyler, 1949). However, “...one of the challenges faced by faculty who use service-learning...is the assessment of student learning outcomes" (Molee, Henry, Sessa, \& McKinney-Prupis, 2010, p. 252). Perhaps this explains why, "there are very few studies which demonstrate the impact of service-learning projects on students' overall learning outcomes" (Salam, Iskandar, Ibrahim, \& Farooq, 2019, p. 574). The value of student learning outcomes (SLOs) is that when they are aligned with AS-L activities within a standards-based curriculum (Bettencourt, 2015; Bringle \& Hatcher, 1996; Salam, Iskandar, Ibrahim, \& Farooq, 2019) the pedagogy can act as an effective assessment tool demonstrating student proficiency of the eight American Library Association (ALA) core competencies (American Library Association Council, 2009).

As an accrediting agency, the expectation of ALA is that all students graduating from an ALAaccredited master's program in library and information studies (LIS) will be able to employ the basic skillsets outlined within the ALA core competencies (American Library Association Council, 2009). While 
ALA is the external accrediting agency charged with auditing LIS graduate programs, it is the faculty members responsibility to design a curriculum that demonstrates its effectiveness through the use of assessments which will "...diagnose student needs...guide our teaching and...enable us, our students, and others...to determine whether we have achieved our goals" (Wiggins \& McTighe, 2005, p. 13). This is how the ALA accrediting body differs from the faculty member. That is, the external accrediting agency audits the evidence gathered by the faculty member in order to assess "...that students are really learning what they are supposed to learn... and to...ensure that consumers get what they pay for..." (Norris, 2006, p. 577). The faculty member utilizes this same "...evidence internally for making decisions and revising program practices" (Norris, 2006, p. 577).

For the LIS faculty member, adjustments to program practices using periodic self-assessments should be an integral part of LIS curriculum design and instruction because "the aim of assessment is primarily to educate and improve student performance, not merely to audit it" (Wiggins, 1998, p. 7). But how does one determine if academic service-learning assessment activities are properly aligned with intended student learning outcomes (SLOs) and American Library Association (ALA) core competencies when faculty have traditionally "...struggled with problems associated with the design and implementation of accountability programs, standards-based curriculums, and authentic assessments" (Anderson et al., 2001, p. xxii)? The answer to this question can be found by conducting an alignment study (Cohen, 1987; Tam, 2013).

\section{BACKGROUND AND THEORETICAL FRAMEWORK - IMPROVING THE STANDARDS- ASSESSMENT-INSTRUCTION CYCLE THROUGH ALIGNMENT RESEARCH}

"Despite the growing popularity of service-learning, it is still unclear what student [learning] outcomes are associated with service-learning programs" (Celio, Durlak, \& Dymnicki, 2011, p. 165). Making explicit connections between intended student learning outcomes (SLOs) and service-learning assessment activities has been linked in some studies to stronger student academic engagement and performance outcomes (Billig, Root, \& Jesse, 2005; Voss, Mathews, Fossen, Scott, \& Schaefer, 2015), larger increases in problemsolving and critical-thinking skills (Asghar \& Rowe, 2017; Barth, Adomßent, Fischer, Richter, \& Rieckmann, 2014; Conrad \& Hedin, 1982), and improved learning and satisfaction with academic programs (Fullerton, Reitenauer, \& Kerrigan, 2015; Hamilton \& Zeldin, 1987). However, given today's standardsbased curriculum within the online teaching and learning environment of higher education, it is necessary for faculty engaged in course construction and design to ensure service-learning assessment activities are properly aligned with intended student learning outcomes and curriculum standards for successful demonstration of student achievement and continued accreditation within one's academic field of study (Angel, 2016; Voss et al., 2015).

"'Alignment' is a principle in curriculum theory that assessment tasks should be aligned to what is intended to be learned, as in criterion-referenced assessment" (Biggs \& Tang, 2011, p. 97). Therefore, the assessment of student work is measured not against other students but against ".... a set of pre-determined criteria for either that course or that particular assessment item and therefore achieves greater transparency in grading" (Chardon et al., 2011, p. 232). When constructing a competency-based course for an accredited LIS program, it is imperative for the faculty member to clearly define the student tasks that are being measured. These measurements are defined through the intended SLOs which are structured according to "...the learning-based model focusing on what students know and can actually do" (Tam, 2013, p. 159). Gallagher (2012) defines student learning outcomes as "statements identifying what students will know or be able to do at the end of an activity, unit of instruction, course, or program of study (p. 44). They "....represent what is formally assessed and accredited to the student and they offer a starting point...for the design of curricula in higher education..." (Allan, 1996, p. 93). Within the context of a competency-based program such as library and information studies, clearly defined student learning outcomes provide the evidence needed for continuous course appraisal and approval for (re)accreditation by ALA-CoA. Most importantly, SLOs are the starting point for making improvements to demonstrated student achievement of ALA core competencies, assessing the quality of course design and effectiveness, and improved teaching (Biggs, 1996; Biggs \& Tang, 2011; Cohen, 1987; Tam, 2013). 
Outcomes-based assessments within competency-based programs are used as a measure in determining student achievement because "...they indicate to teachers, students, and the public the specific results expected from participation in a program" (Norris, 2006, p. 557). When student learning outcomes are used within the framework of alignment research then faculty can analyze "on a course-by-course basis as well as from a program-wide perspective" (Bettencourt, 2015, p. 475) if students demonstrate proficiency of intended learning outcomes via graded assessment activities which can then be used "...to make data-based decisions..." (Bettencourt, 2015, p. 475) for sustained program evaluation and improvement. If one incorporates academic service-learning assessment activities into the curriculum, then the influence of service-learning on student proficiency of intended student learning outcomes can also be measured. This use of alignment research within a competency-based program that integrates academic service-learning assessment activities is what is known as the theory of constructive alignment (Biggs, 1996; Biggs \& Tang, 2011; Tam, 2013).

The theory of constructive alignment is a melding of two different schools of thought; constructive learning theory and the instructional design literature (Biggs, 1996; Biggs \& Tang, 2011; Tam, 2013). Constructivist theory postulates that students are not empty vessels waiting to be filled but enter the classroom with their own previously learnt knowledge and experiences (Biggs, 1996; Biggs \& Tang, 2011; Dames, 2012; Harland, 2003). The term 'alignment' is a principle utilized in the instructional design literature that prescribes assessment activities should match the learning outcomes students are expected to achieve within a competency-based program (Biggs, 1996; Biggs \& Tang, 2011; Tam, 2011). Operating under this constructivist perspective (Biggs, 1996; Biggs \& Tang, 2011; Dames, 2012; Harland, 2003), adoption of the academic service-learning teaching pedagogy allows the faculty member to use the realworld environment in constructing student learning outcomes that demonstrate proficiency within a competency-based program such as library and information studies. Aided by the service-learning community, the faculty member is provided with the opportunity to partner with information professionals working in the field who then become co-teachers in aiding the student in making the shift from LIS theory to LIS practice (Angel, 2016).

With the academic service-learning assessment activities aligned to the intended student learning outcomes and couched within the real-world environment, students are provided with a platform that enables them to construct their own knowledge and demonstrate proficiency of the ALA core competencies through the service-learning assignments they construct and reflect upon in their ePortfolios (Angel \& Robinson, 2017). By adopting these "practice-focused learning experiences" (Ruge, Tokede, \& Tivendale, 2019, p. 840) students can demonstrate to ALA-CoA proficiency of ALA core competencies which are assessed utilizing the principle of constructive alignment (Biggs, 1996; Biggs \& Tang. 2011; Cohen, 1987) and, in turn, demonstrate what they can actually do to potential employers within the field. These "practicefocused learning experiences" (Ruge, Tokede, \& Tivendale, 2019, p. 840) are then verified through the artifacts they select and reflect upon within their ePortfolios (Angel \& Robinson, 2017) which are also assessed utilizing the principle of constructive alignment (Biggs, 1996; Biggs \& Tang. 2011; Cohen, 1987).

According to Webb (2002), the "alignment of expectations for student learning and assessments for measuring students' attainment of these expectations is an essential attribute for an effective standardsbased education system" (p. 1). Alignment research provides a quantitative method for faculty engaged in action research to evaluate the degree to which assessment activities match intended student learning outcomes and curriculum standards in higher education. The term alignment is defined by Fulmer, Tanas, and Weiss (2018) as, "the degree of agreement or match between a set of educational standards and the assessments, curriculum materials, or instructional practices that are intended to address them" (p. 1077). The benefit of conducting an alignment study is that it provides faculty members engaged in curriculum design and instruction with ".... systematic way to judge the degree of agreement with targeted standards, yields insights into possible misalignment, and informs efforts to refine assessments, educational materials, and teaching to improve the match with standards" (Fulmer, Tanas, \& Weiss, 2018, p. 1077).

There are two additional types of alignment research commonly found within the literature: instructional alignment and curricular alignment. "In a classroom setting, instructional alignment refers to the agreement between a teacher's objectives, activities, and assessments so they are mutually supportive" 
(Martone \& Sireci, 2009, p. 1334). According to Cohen (1987), "instructional alignment describes the extent to which stimulus conditions match among three instructional components: intended outcomes, instructional processes, and instructional assessment" (p. 16). Martin (2011) defines instructional alignment as "...the process by which the different instructional elements are connected to each other and, in the end, makes the instructional material more effective" (p. 962). Instructional alignment differs from the previously discussed theory of constructive alignment in that instructional alignment does not necessarily implement the learn-by-doing teaching pedagogy.

The purpose of this study was to obtain an understanding of the degree of alignment among academic service-learning assessment (AS-L) activities, intended student learning outcomes and ALA curriculum standards through the analysis of student post-reflections in one required online library and information studies (LIS) graduate course. The value in conducting such a study is that "once the degree of alignment is understood, subsequent changes in any of the educational components can be made to improve the standards-assessment-instruction cycle" (Martone \& Sireci, 2009, p. 1335).

The significance of this study lies in the fact that few researchers within the field of LIS have used student post-reflections as evidence in determining if intended student learning outcomes are clearly aligned to academic service-learning assessment activities and ALA curriculum standards (Celio, Durlak, \& Dymnicki, 2011; Salam, et al., 2019; Voss, et al., 2015). The benefit in allowing students to "articulate their learning through their reflections" (Molee et al., 2010, p. 241) is that it provides an additional reference point that can be used in conjunction with standardized test scores (La Marca, 2001; Pelton, 2010) to understand and improve the degree of alignment among AS-L assessment activities, intended SLOs, and curriculum standards. More importantly, once the degree of alignment is understood action can then be taken by the faculty researcher to correct possible misalignments and refine service-learning assessment activities which will result in an improved match between SLOs and ALA curriculum standards.

The main research question posed within this study was to determine which learning outcomes are directly associated with AS-L assessment activities in one required online library and information studies course as evidenced by student post-reflections. Within this main research question two sub-questions were posed. The first sub-question was to determine if student post-reflections demonstrate evidence of achievement between service-learning assessment activities and intended student learning outcomes. The goal in answering this question was to determine if the AS-L activity properly acts as the assessment in demonstrating student achievement in each of the intended learning outcomes. The second sub-question posed was to determine if student post-reflections demonstrate differences in achievement among the intended student learning outcomes when participating in online versus onsite academic service-learning projects. The goal in answering this question was to determine if face-to-face (F2F) or online servicelearning community partners were more appropriate for assessing student proficiency of intended learning outcomes.

In answering these questions, the faculty researcher intended to meet the following objectives. The first objective was to determine if the student learning outcomes are aligned between service and learning as evidenced by student post-reflections. If data analysis indicates they are not, then what assignments and service-learning activities need to be changed in order to correct any misalignments within the course? The second objective was to determine if the intended student learning outcomes are aligned to the appropriate ALA curriculum standards as evidenced by student post-reflections. If data analysis indicates there is a misalignment between/among student learning outcomes and ALA curriculum standards, then what student learning outcomes need to be changed in order to rectify this misalignment? The third objective was to determine if student post-reflections demonstrate evidence of achievement of the ALA curriculum standard (or core competency) identified within the course. If data analysis indicates there is a misalignment between student post-reflections and ALA curriculum standards, then does an additional ALA curriculum standard need to be added to the course?

Results of this analysis will determine what changes, if any, need to be made to the (a) service-learning assessment activities, (b) the intended student learning outcomes, and (c) the ALA curriculum standards identified for the course. The intended goal in correcting any misalignments was to increase the quality of the course curriculum design and instruction in order to better demonstrate evidence of student achievement 
of ALA core competencies (American Library Association Council, 2009) to the programs external accrediting agency, the American Library Association - Committee on Accreditation (ALA-CoA) (American Library Association Office for Accreditation, 2019).

\section{THE CURRICULUM-PROGRAM-COURSE ALIGNMENT PROCESS}

According to the Council for Higher Education Accreditation (CHEA) Committee on Recognition, the American Library Association-Committee on Accreditation (ALA-CoA), "accredits master's programs in library and information studies offered under the degree-granting authority of institutions in the United States, its territories, possessions, and protectorates; in Canada by agreement with the Canadian Federation of Library Associations...; and in the United Kingdom" (Council for Higher Education Accreditation, 2019a, p. 1). As an accrediting agency, ALA-CoA is required "...to ensure that accredited programs provide timely, readily accessible, accurate, and consistent aggregate information to the public about programmatic performance and student achievement" (Council for Higher Education Accreditation, 2019b, p. 1).

Student achievement is demonstrated through the courses taught by LIS faculty to ALA-CoA via the American Library Association's eight core competencies (American Library Association Council, 2009). The eight core competencies identified by the American Library Association are the measures against which the ALA curriculum standards are assessed (See Table 1).

\section{TABLE 1}

\section{AMERICAN LIBRARY ASSOCIATION (ALA) CORE COMPETENCIES}

1. Foundations of the Profession

2. Information Resources

3. Organization of Recorded Knowledge and Information

4. Technological Knowledge and Skills

5. Reference and User Services

6. Research

7. Continuing Education and Lifelong Learning

8. Administration and Management

Note. The ALA Core Competencies along with the corresponding Sub-Competencies can be found at http://www.ala.org/educationcareers/careers/corecomp/corecompetences

However, the expectation from ALA-CoA is that all ALA accredited programs will differ slightly in their performance based upon their parent institution's mission. That is, "the program's goals and objectives are consistent with the values of the parent institution and the culture and mission of the program..." (Council of the American Library Association, 2019, p. 4). As such, when ALA-CoA reaccredited the Division of Library and Information Science (DLIS) graduate program at St. John's University it was expected that the program was going to vary slightly from others because the programmatic goals and outcomes which guide the Division's performance are couched within the Vincentian Mission of the University (American Library Association, 2008). This means when SJU DLIS developed their departmental learning goals and outcomes, the program was framed by defining its mission statement first, making sure that it reflects the Vincentian Mission of its parent institution. Then, the American Library Association's (ALA) eight core competencies were aligned to the DLIS programmatic goals and learning outcomes within this Vincentian framework (St. John's University, 2020). It is within this context that course construction and design demonstrating successful student achievement of ALA core competencies can begin.

The context of this constructivist alignment study took place within an SJU DLIS core course titled LIS 203: Organization of Information. The course was developed by the faculty member with the intention that students would be able to demonstrate evidence of achievement in meeting ALA core competency number 
three: "Organization of Recorded Knowledge and Information" (American Library Association Council, 2009). This ALA core competency along with three associated sub-competencies were aligned with a subset of DLIS learning goals and outcomes. These departmental learning goals and outcomes were then crosswalked to the LIS 203 course.

When constructing the LIS 203 course, five learning outcomes were identified representing what students would be able to do upon completion of the subject studied. Assessments in the form of academic service-learning (AS-L) activities were then identified for each of the five intended student learning outcomes (SLOs). The assessments were constructed so that they became the evidence to ALA-CoA demonstrating what students would be able to do upon completion of the subject studied. The assessments also act as a measurement tool demonstrating the effectiveness of the LIS 203 course design and instruction delivered by the faculty member. The goal in setting up the course using this framework was so that students, administrators, and the external accrediting agency (ALA-CoA) could clearly understand: (a) which assessments demonstrate evidence of student achievement for each of the five intended SLOs, which are then aligned to (b) the appropriate DLIS program goals, and (c) the identified ALA core competency. The LIS 203: Organization of Information course alignment chart can be found in Appendix A.

\section{METHOD}

\section{Method of Inquiry}

Action research was used as the method of inquiry within this study in order to determine how accurate student learning outcomes were aligned with academic service-learning assessment activities and ALA curriculum standards in a LIS 203: Organization of Information graduate course. "Action research...is a systematic approach to improve teaching practices" (Pelton, 2010 p. 3). It is defined by Mills (2003) as "any systematic inquiry conducted by teacher researchers, principals, school counselors, or other stakeholders in the teaching/learning environment to gather information about how their particular schools operate, how they teach, and how well students learn" (p. 5). Action research, when paired with the results of an alignment study, can provide evidence on how well assessments match intended student learning outcomes and ALA curriculum standards. These results can then be used to improve the quality of course design, teaching practices, and student achievement of ALA curriculum standards. As such, implementing action research as the investigative model within this constructive alignment study allowed the faculty researcher to evaluate misalignments within the course, refine intended student learning outcomes, and improve upon demonstrated student performance of ALA curriculum standards.

\section{Participants, Data Sources, and Inclusion Criteria}

A total of 124 students were enrolled in the online LIS 203 graduate course over a five-year period. Of these 124 students, a total of 96 data points were measured (See Table 2). Total number of measurable data points were assessed via completeness of data. Incomplete data accounted for a variety of reasons such as (a) the student failing to complete the assignment, (b) failure of the student to follow instructions and complete all components of the assignment, and (c) students dropping the course. Students coded as "Graduate Assistants" were not included in the final data count. Finally, four data files downloaded from the learning management system were corrupt and therefore unusable. 
TABLE 2

MEASURABLE DATA POINTS ASSESSED

\begin{tabular}{|c|c|c|}
\hline Semester & Total Students/Semester & Measurable Data Points \\
\hline 1 & 23 & 19 \\
\hline 2 & 33 & 25 \\
\hline 3 & 18 & 13 \\
\hline 4 & 32 & 26 \\
\hline 5 & 17 & 13 \\
\hline
\end{tabular}

Previously graded assignments were not used for this data analysis. The reason for this is because comments were added by the faculty researcher while marking final grades and it was not known if the SPSS statistical software package would encounter difficulties in reading this information. Additionally, in order to protect the anonymity of the students, it was desirable to mitigate any identifiable information. As such, all assignments were pulled from archived data within the learning management system.

\section{Coding Procedures}

Four coders analyzed post-reflection data from 96 students over a five-year period. The LIS 203: Organization of Information course was taught once every spring semester. This meant that five semesters of data were analyzed. Data coding meetings took place twice per week over a period of three months to determine the data coding methodology. The coders used student post-reflections from the first semester to create the methodology and the data coding alignment chart (Appendix B) for the coding schema. As such, the first 19 subjects were not used in determining interrater reliability. The additional four semesters were implemented in the data analysis. This resulted with a total of 77 subjects. It took an additional four months to implement the data coding process using the newly created alignment chart to code the student postreflections. The procedure implemented for the data coding process involved each of the four coders reviewing student post-reflections in sets of ten. Each set of post-reflection data was reviewed against the data coding alignment chart by all four coders individually. Then, the four coders would meet for one hour two times per week in order to compile data and discuss results.

Data was coded using a binary system of zero's and one's. A zero [" 0 "] was annotated if the coder determined that the student post-reflection did not demonstrate evidence of achievement in meeting the intended learning outcome. A one ["1"] was annotated if the coder determined that the student postreflection did demonstrate evidence of achievement in meeting the intended learning outcome. After the 77 post-reflections were coded, data from all four coders was compiled into one Excel spreadsheet in the form of a stoplight chart (See Table 3). This data was organized by the five student learning outcomes (SLOs), per coder, for each of the 77 subjects. This data was then used to determine interrater reliability among the four coders. 
TABLE 3

\section{CODED DATA STOPLIGHT CHART EXAMPLE AMONG FOUR CODERS ASSESSING 77 POST-REFLECTIONS AGAINST FIVE LEARNING OUTCOMES FOR ONE LIS GRADUATE COURSE}

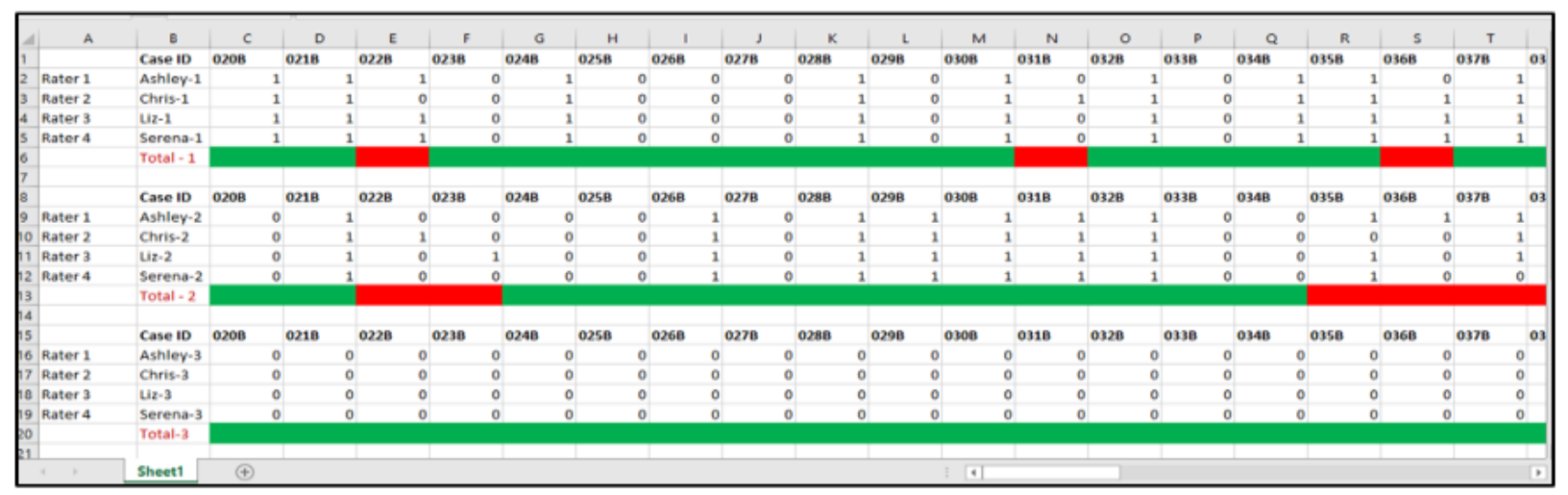

Note. This is an example of the summarized data used within the Excel spreadsheet in order to determine interrater reliability among the four coders.

As Table 3 demonstrates, each of the five student learning outcomes (SLOs) were grouped with the corresponding rater data for each of the 77 coded subjects. For each of the five SLOs assessed, the four coders were organized by the rater's name and the SLO number measured. So, for the first SLO measured, each of the four coders are represented by "Ashely-1," "Chris-1," Liz-1, and "Serena-1." Each of the 77 subjects within the study are represented in columns by a unique four-digit alphanumeric Case-ID. These numbers are shown in Table 3 in bold and are located in the first row above each student learning outcome being measured. For each SLO and Case-ID the coded data is organized by "zero" or "one" indicating the coders judgement in determining if the student post-reflections demonstrated no achievement or achievement for each of the five SLOs. The total number of agreements and disagreements among the four coders was then assessed for each SLO within the Excel spreadsheet. The color "red" represents disagreement among the four coders when determining if the subject, represented by Case-ID, demonstrated no achievement ["0"] or achievement ["1"] of the intended student learning outcome (SLO). The color "green" indicates there was agreement among all four coders when determining if the subject demonstrated no achievement [" 0 "] or achievement [" 1 "] of the intended student learning outcome. Upon completion of the data coding process, the reliability of the measurement tool needed to be determined.

\section{Interrater Reliability}

According to Salkind (2017) reliability is determining “...whether a test or whatever you use as a measurement tool, measures something consistently" (p. 111). There are four different types of reliability measurement identified by Salkind (2017): (a) test-retest, (b) parallel forms, (c) internal consistency, and (d) interrater reliability. The type of reliability measurement used for this study was interrater reliability. This type of reliability is used "when you want to know whether there is consistency in the rating of some outcome" (Salkind, 2017, p. 113). More specifically, "interrater reliability is the measure that tells you how much two [or more] raters agree on their judgements of some outcome" (Salkind, 2017, p. 120). Interrater reliability is calculated by examining the percentage of agreement between or among raters. For this constructive alignment study, there were four different raters, or coders. As such, the percentage of agreement among the four coders was examined from the stoplight chart in Table 3. From this data, interrater reliability was then calculated by assessing the number of agreements over the number of possible agreements (See Figure 1). 
FIGURE 1

INTERRATER RELIABILITY FORMULA

\author{
Interrater Reliability $=$ Number of Agreements \\ Number of Possible Agreements
}

To determine interrater reliability among the four coders for the five student learning outcomes (SLOs) and 77 subjects the interrater reliability for each individual SLO was calculated first. Then the total number of agreements among all four coders for the five learning outcomes and 77 subjects involved in the study were calculated. In this way, the faculty researcher was able to verify interrater reliability for each individual student learning outcome and for the total number of outcomes under observation.

If all four coders determined that the subject under observation did not demonstrate achievement [" 0 "] or did demonstrate achievement [" 1 "] of the SLO under observation, then the total for that subject was marked as green and therefore represented an agreement among all four coders. If there was a lack of agreement among all four coders when determining if the subject under observation did not demonstrate ["0"] or did demonstrate ["1"] achievement of the SLO under observation, then that subject was marked as red. As such, for the first student learning outcome, out of 77 possible agreements, there was a total of 56 agreements among the four coders that the subject either did or did not demonstrate achievement of the first SLO. This means that interrater reliability among the four coders for the first student learning outcome was calculated at 0.7272 (Figure 2).

FIGURE 2

INTERRATER RELIABILITY AMONG THE FOUR CODERS CALCULATED FOR THE 77 SUBJECTS INVOLVED IN THE CONSTRUCTIVE ALIGNMENT STUDY FOR STUDENT LEARNING OUTCOME NUMBER ONE (SLO1)

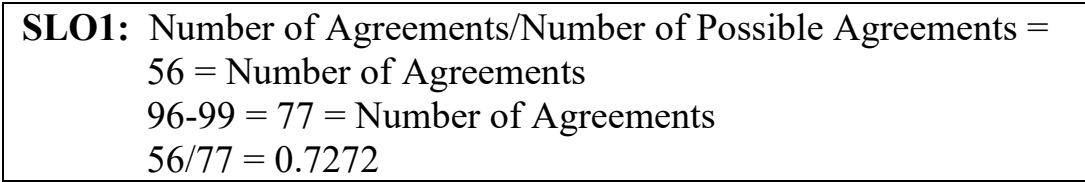

This same process was repeated for each student learning outcome so that the total number of agreements among the four coders could be calculated. There was a total of 313 agreements among the four coders for all five student learning outcomes measured. Then the total number of possible agreements was determined by multiplying the total number of subjects (77) by the total number of SLOs (5) which equated to 385 possible agreements. To determine interrater reliability, the total number of agreements divided by the total number of possible agreements was calculated at 0.81298 (Figure 3).

FIGURE 3

\title{
TOTAL NUMBER OF AGREEMENTS AMONG THE FOUR CODERS DIVIDED BY THE TOTAL NUMBER OF POSSIBLE AGREEMENTS FOR EACH LEARNING OUTCOME MEASURED
}

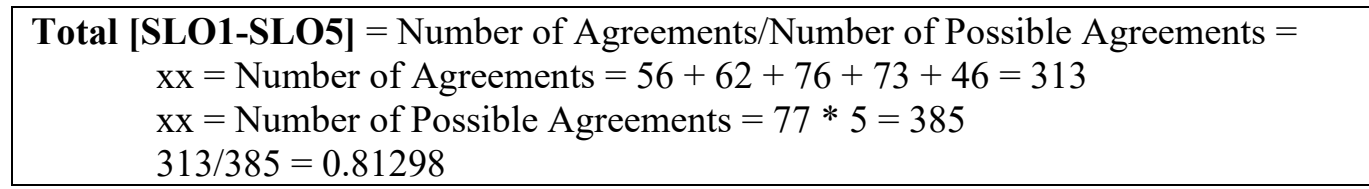

This means that the interrater reliability for the 77 student post-reflections demonstrating evidence of no achievement ["0"] or achievement [" 1 "] against each of the five intended student learning outcomes 
(SLOs) among the four coders was high, indicating, of course, a high degree of agreement among the four coders. This is interpreted such that the measurement tool used within this study - the data coding alignment chart - indicates that the four coders were essentially consistent with one another in their agreements when rating the 77 student post-reflections against each of the five intended student learning outcomes. This also means that the data coding procedure used within this constructive alignment study is reliable because the level of agreement among the four coders when compared to the occurrence of observed behaviors was high. The importance of this information lies in the fact that there is demonstrated usefulness in the data coding alignment tool used to measure the influence of academic service-learning assessment activities among 77 subjects for all five pre-defined student learning outcomes.

Next, SPSS was used to calculate the descriptive statics. The coded data was defined within SPSS as either "Valid" or "Missing." Valid data was defined as all four coders agreed that (a) students did not demonstrate achievement ["0"] within the student learning outcome measured or (b) students did demonstrate achievement ["1"] within the student learning outcome measured. Missing data was defined within SPSS as no agreement among the four coders. In other words, if there was no agreement among all four coders then the data was thrown out. Table 4 summarizes the frequency of agreements and disagreements among the four coders when assessing if the 77 student post-reflections demonstrated evidence of achievement for each of the five intended student learning outcomes for the LIS 203: Organization of Information course.

\section{TABLE 4}

\section{FREQUENCY OF AGREEMENTS \& DISAGREEMENTS AMONG FOUR CODERS WHEN ASSESSING DEMONSTRATED STUDENT ACHIEVEMENT OF FIVE DIFFERENT LEARNING OUTCOMES IN ONE ONLINE GRADUATE COURSE}

\begin{tabular}{|c|l|c|c|c|c|c|c|}
\hline \multicolumn{9}{|c|}{ Statistics } \\
\hline \multirow{2}{*}{$\mathrm{N}$} & & CaseID & SLO1 & SLO2 & SLO3 & SLO4 & SLO5 \\
\cline { 2 - 8 } & Valid & 77 & 56 & 62 & 76 & 73 & 46 \\
\cline { 2 - 8 } & Missing & 0 & 21 & 15 & 1 & 4 & 31 \\
\hline
\end{tabular}

So, if we look at the Valid and Missing SPSS data according to each of the five student learning outcomes, Table 4 demonstrates the agreement and disagreement among each of the four coders. The valid data represents agreement among the four coders and the missing data represents disagreement among the four coders. For example, if we look at the first student learning outcome (SLO1) the data is interpreted as: Of the 77 subjects analyzed, the four coders agreed that 56 students demonstrated either (a) no achievement ["0"] or (b) achievement ["1"] of the first student learning outcome as evidenced by student post-reflections. Additionally, of the 77 subjects analyzed, there was disagreement among the four coders in determining if 21 students demonstrated either (a) no achievement ["0"] or (b) achievement ["1"] of SLO1 as evidenced by student post-reflections. If there was no agreement amongst all four coders then the data was thrown out, hence the Missing value used in SPSS. This same method of interpretation is continued for SLO2 through SLO5. Upon verifying that the data coding alignment chart was a reliable tool to use for this study the faculty researcher was then able to find answers to the main research question posed within this constructive alignment study which was to determine if the five intended learning outcomes defined within the LIS 203: Organization of Information course were directly associated with academic service-learning assessment activities as evidenced by student post-reflections.

\section{RESULTS}

The main research question posed within this study was to determine which learning outcomes are associated with AS-L assessment activities in one required online library and information studies graduate course as evidenced by student post-reflections. Within this main research question two sub-questions were posed. The first sub-question was to determine if student post-reflections demonstrate evidence of 
achievement between service-learning assessment activities and intended student learning outcomes. The goal in answering this question was to determine if the AS-L activity properly acts as the assessment in demonstrating student achievement within each of the five intended learning outcomes. Table 5 summarizes the student learning outcomes used by the faculty researcher to assess demonstrated student achievement within the LIS 203 Organization of Information course.

\section{TABLE 5 \\ SUMMARY OF THE FIVE STUDENT LEARNING OUTCOMES WITHIN THE LIS 203 ORGANIZATION OF INFORMATION COURSE}

\begin{tabular}{l}
\hline Five LIS 203 Student Learning Outcome Measured (Abbreviated Format) \\
SLO1 Deal w/ Different Types of Resources \& Explain Rules \\
SLO2 Standards in Data Structure, Content \& Values \\
SLO3 Advantages \& Disadvantages of Bibliographic Systems \\
SLO4 Create Interoperable Data Standards \\
SLO5 Work Comfortably w/in the Digital Environment \\
\hline
\end{tabular}

The second sub-question posed within this study was to determine if student post-reflections demonstrate differences in achievement among the intended student learning outcomes when participating in online versus onsite academic service-learning projects. The goal in answering this question was to determine if face-to-face (F2F) or online service-learning community partners were more appropriate for assessing student proficiency of intended learning outcomes.

\section{Demonstrated Evidence of Student Achievement}

The goal of the first intended student learning outcome (SLO1) was for students to be able to deal with different types of information resources and be able to explain the concepts behind the rules and systems used in order to provide intellectual access to different media types found within library's, archives, and museums (LAMs) (Figure 4). There were two research questions associated with the first intended student learning outcome. The first research question associated with SLO1 was to determine if the incorporation of academic service-learning assessment activities influenced student achievement in understanding how to work with different types of information resources. The second research question associated with SLO1 was to determine if the incorporation of academic service-learning assessment activities influenced student achievement in the understanding of concepts behind the rules and systems used to provided intellectual access to different media types found within library's, archives, and museums (LAMs).

\section{FIGURE 4 \\ DEMONSTRATED EVIDENCE OF STUDENT ACHIVEMENT BETWEEN ACADEMIC SERVICE-LEARNING ASSESSMENT ACTIVITIES \& INTENDED STUDENT LEARNING OUTCOME NUMBER ONE AS EVIDENCED BY STUDENT POST-REFLECTION ASSIGNMENTS}

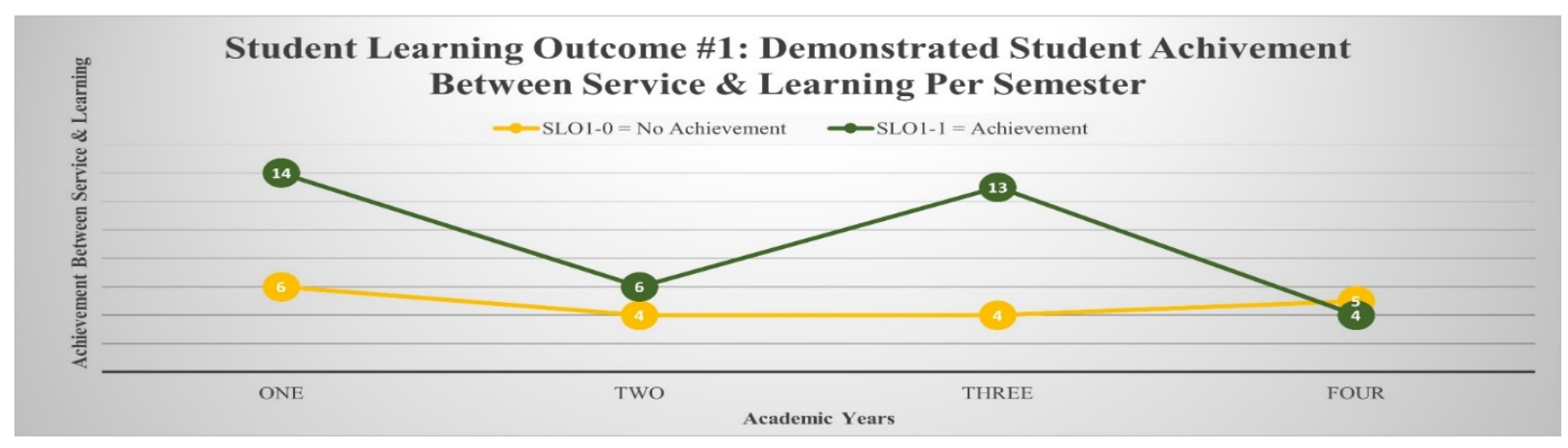


Results for SLO1 indicate that the incorporation of academic service-learning assessment activities had a positive effect in demonstrated student achievement for the first intended student learning outcome during the first, second, and third semesters but a negative effect during the fourth semester.

The goal of the second intended student learning outcome (SLO2) was for students to be able to provide examples of standards in data structure, data content, and data values. The research question related to SLO2 was to determine if the incorporation of service-learning assessment activities influenced student achievement in being able to provide examples of standards in data structure, data content, and data values.

\section{FIGURE 5 \\ DEMONSTRATED EVIDENCE OF STUDENT ACHIVEMENT BETWEEN ACADEMIC SERVICE-LEARNING ASSESSMENT ACTIVITIES \& INTENDED STUDENT LEARNING OUTCOME NUMBER TWO AS EVIDENCED BY STUDENT POST-REFLECTION ASSIGNMENTS}

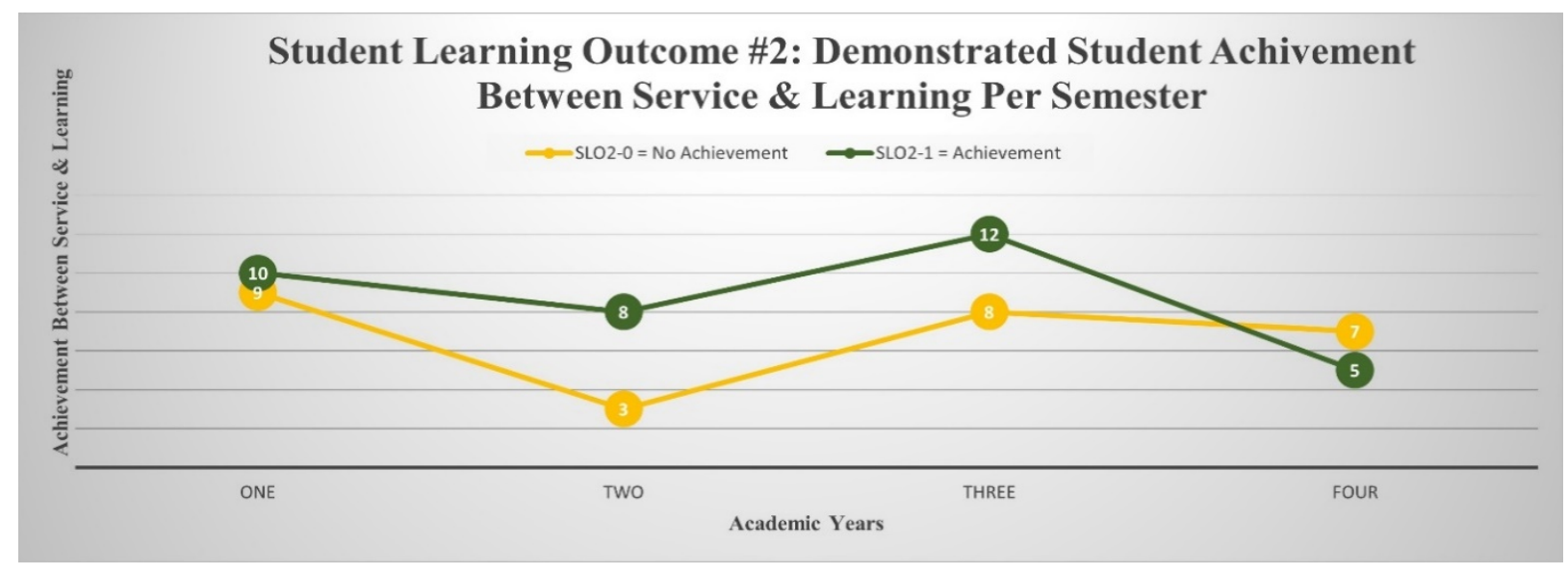

Results for the second student learning outcome (SLO2) indicate that the incorporation of academic servicelearning assessment activities did influence student achievement as demonstrated by student post-reflection assignments during the first, second, and third semester but did not influence student achievement during the fourth semester. These results are comparable to the first student learning outcome measured.

The goal of the third intended student learning outcome (SLO3) was for students to be able to critically analyze the advantages and disadvantages of different types of bibliographic systems used within different information environments. The research question related to SLO3 was to determine if the incorporation of academic service-learning assessment activities influenced student achievement in one's ability to critically analyze the advantages and disadvantages of different types of bibliographic systems. 
FIGURE 6

\section{DEMONSTRATED EVIDENCE OF STUDENT ACHIVEMENT BETWEEN ACADEMIC SERVICE-LEARNING ASSESSMENT ACTIVITIES \& INTENDED STUDENT LEARNING OUTCOME NUMBER THREE AS EVIDENCED BY STUDENT POST-REFLECTION ASSIGNMENTS}

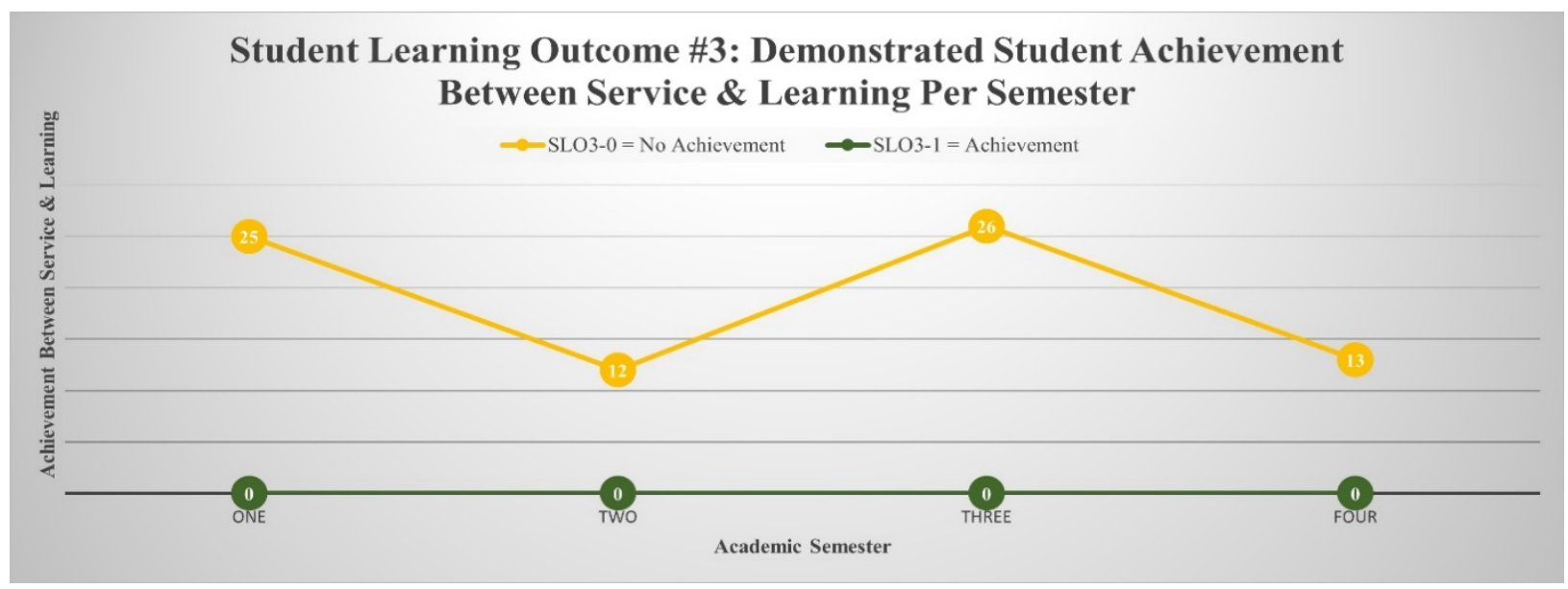

Results for the third student learning outcome indicate that the incorporation of academic service-learning assessment activities did not influence student achievement in one's ability to critically analyze the advantages and disadvantages of different types of bibliographic systems.

The goal of the fourth student learning outcome (SLO4) was for student's to be able to take their specific community data content standards and make them interoperable across different information environments utilizing different data content standards. The research question associated with SLO4 was to determine if the incorporation of academic service-learning assessment activities influenced student achievement in being able to take community specific content standards and make them interoperable across different information environments utilizing different data content standards.

\section{FIGURE 7 \\ DEMONSTRATED EVIDENCE OF STUDENT ACHIVEMENT BETWEEN ACADEMIC SERVICE-LEARNING ASSESSMENT ACTIVITIES \& INTENDED STUDENT LEARNING OUTCOME NUMBER FOUR AS EVIDENCED BY STUDENT POST-REFLECTION ASSIGNMENTS}

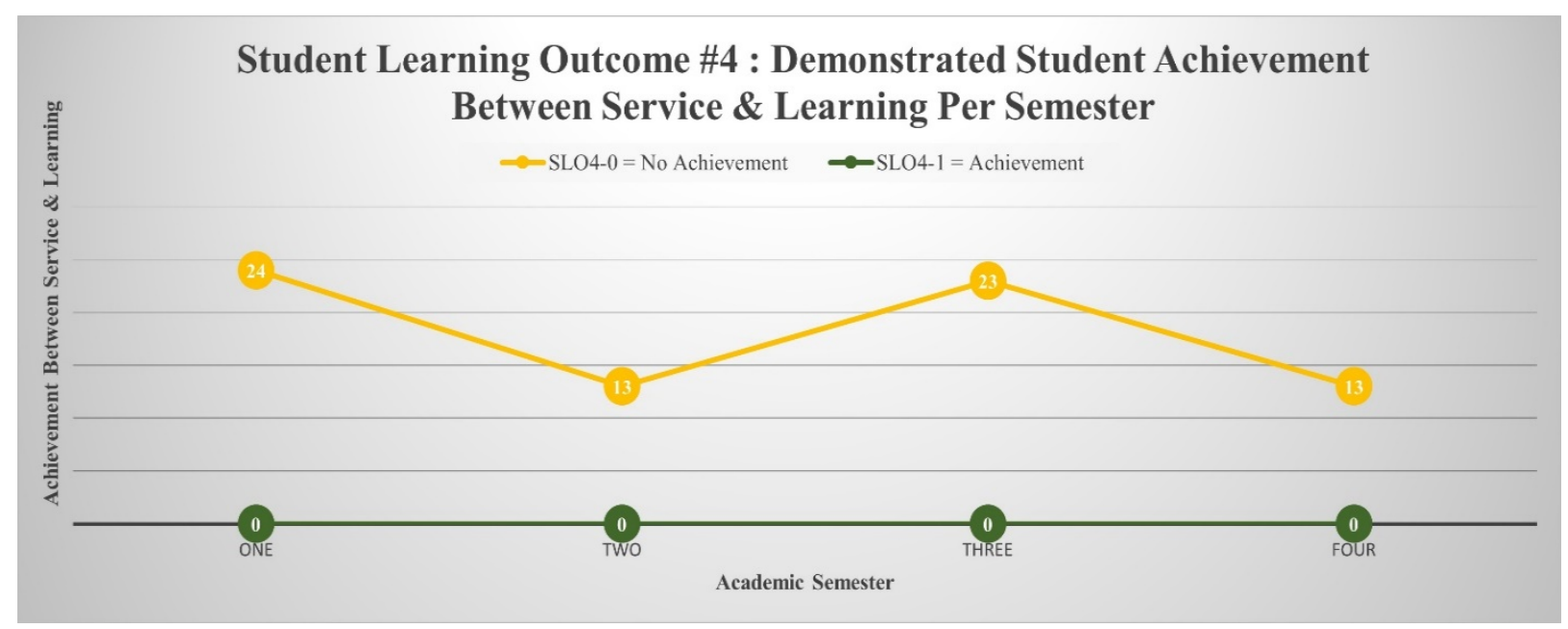


Results for SLO4 indicate the incorporation of academic service-learning assessment activities did not influence student achievement in being able to take specific community data content standards and make them interoperable across different information environments utilizing different data content standards.

The goal for the fifth and final intended student learning outcome (SLO5) was for students to be able to work comfortably within the emerging digital information environment. The research question associated with SLO5 was to determine if the incorporation of academic service-learning assessment activities influenced student achievement in being able to work comfortably within the emerging digital information environment.

\section{FIGURE 8 \\ DEMONSTRATED EVIDENCE OF STUDENT ACHIEVEMENT BETWEEN ACADEMIC SERVICE-LEARNING ASSESSMENT ACTIVITIES \& INTENDED STUDENT LEARNING OUTCOME NUMBER FIVE AS EVIDENCED BY STUDENT POST-REFLECTION ASSIGNMENTS}

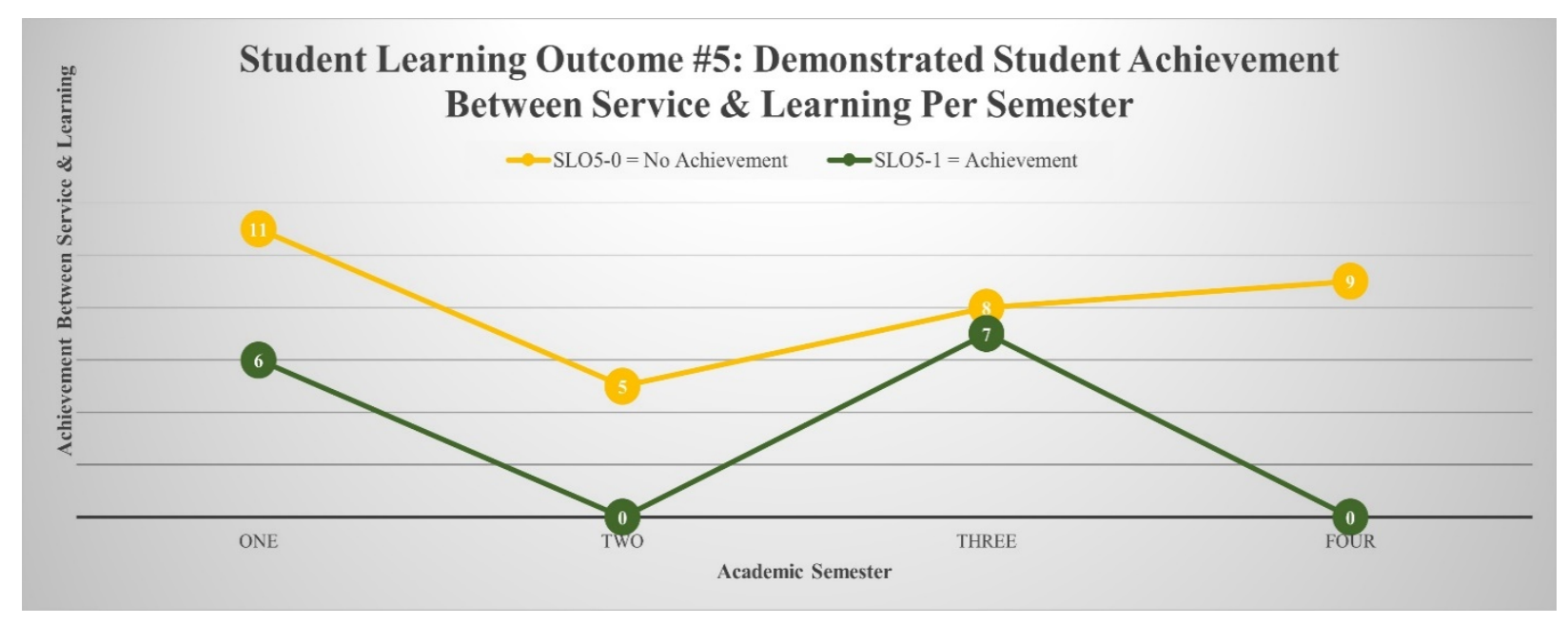

Results for SLO5 were mixed as the incorporation of service-learning assessment activities had some influence on student achievement as demonstrated by student post-reflection assignments during the first and third semesters but the results are not strong enough to indicate that there was a positive effect. There was no influence between academic service-learning assessment activities and student achievement in one being able to work comfortably within the emerging digital information environment during the second and fourth academic semesters.

\section{Online Versus Onsite Service-Learning}

With data analysis indicating a positive correlation between demonstrated student achievement for the first, second, and fifth learning outcomes and academic service-learning assessment activities the faculty researcher then wanted to know if there was a difference in student achievement when participating in online versus onsite academic service-learning projects. To find the answer to this question, data was compiled for each student. First, by semester for each of the five student learning outcomes and then by no achievement ["0"] or achievement ["1"]. Then, data was collected indicating if the student participated with an online or a face-to-face (F2F) academic service-learning community partner.

So, for each of the 77 subjects within this study data was first annotated indicating if the student was coded as a zero or one. And as before, a zero ["0"] indicated the student did not demonstrate achievement in the student learning outcome as evidenced by the post-reflection assignment. A one ["1"] indicated that the student did demonstrate achievement of the learning outcome as evidenced by their post-reflection assignment. Then, academic service-learning community partner site data was organized for each student noting if the student participated with an online service-learning community partner or a F2F service- 
learning community partner. A two ["2"] was used to code each student that participated with an online service-learning partner. A three ["3"] was used to code each student that participated with a F2F servicelearning community partner. Then the data was summarized in an Excel file and coded for all possible permutations (See Table 6).

TABLE 6

PERMUTATIONS COMPARING THE NATURE OF ACADEMIC SERVICE-LEARNING EXPERIENCE \& STUDENT ACHIEVEMENT

\begin{tabular}{|l}
$0-2=$ No Achievement w/ Online AS-L \\
$0-3=$ No Achievement w/ F2F AS-L \\
$1-2=$ Achievement w/ Online AS-L \\
$1-3=$ Achievement w/ F2F AS-L
\end{tabular}

Finally, after this information was summarized in an Excel spreadsheet for each student learning outcome the data was graphed and a bivariate regression analysis was performed comparing the nature of the academic service-learning experience (online v. F2F) and student achievement (did not meet v. met) for intended student learning outcomes one, two, and five.

\section{FIGURE 9 \\ DISTRIBUTION OF STUDENT ACHIEVEMENT VERSUS NO ACHIEVEMENT FOR LEARNING OUTCOME ONE WHEN PARTICIPATING WITH ONLINE VERSUS F2F ACADEMIC SERVICE-LEARNING COMMUNITY PARTNERS}

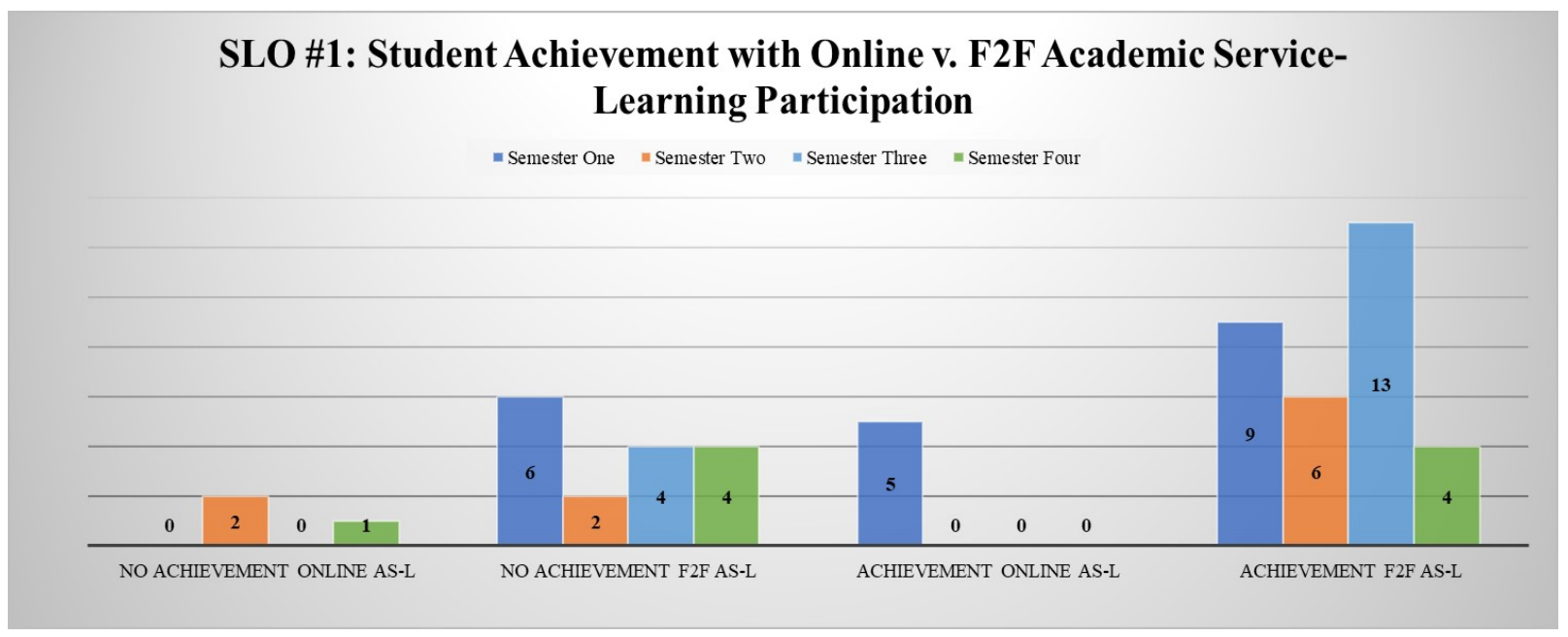

This is what the distribution looks like when graphed for the first student learning outcome for each of the four semesters measured. As evidenced by the data graphed, there is a noticeable increase in student achievement in the first learning outcome when participating with F2F service-learning community partners except for the third semester. However, is this difference statistically significant? 
TABLE 7

BIVARIATE REGRESSION ANALYSIS OF STUDENT ACHIEVEMENT VERSUS NO

ACHIEVEMENT FOR LEARNING OUTCOME ONE WHEN PARTICIPATING WITH ONLINE VERSUS F2F ACADEMIC SERVICE-LEARNING COMMUNITY PARTNERS

\begin{tabular}{|c|c|c|c|c|c|c|c|}
\hline \multicolumn{8}{|c|}{ Variables in the Equation } \\
\hline & & B & S.E & Wald & $\mathrm{df}$ & Sig. & $\operatorname{Exp}(\mathrm{B})$ \\
\hline \multirow{2}{*}{ Step $1^{a}$} & Nature Exp & .588 & .803 & .536 & 1 & .464 & 1.800 \\
\hline & Constant & .511 & .730 & .489 & 1 & .484 & 1.667 \\
\hline
\end{tabular}

Participating within the face-to-face learning environment with academic service-learning community partners increases the odds of students meeting the first learning outcome by a factor of 1.8 , or by $80 \%$ than students who participated with online service-learning community partners. However, because our $p$-value was set at .05 or less, this is not statistically significant.

FIGURE 10

DISTRIBUTION OF STUDENT ACHIEVEMENT VERSUS NO ACHIEVEMENT FOR LEARNING OUTCOME TWO WHEN PARTICIPATING WITH ONLINE VERSUS F2F ACADEMIC SERVICE-LEARNING COMMUNITY PARTNERS

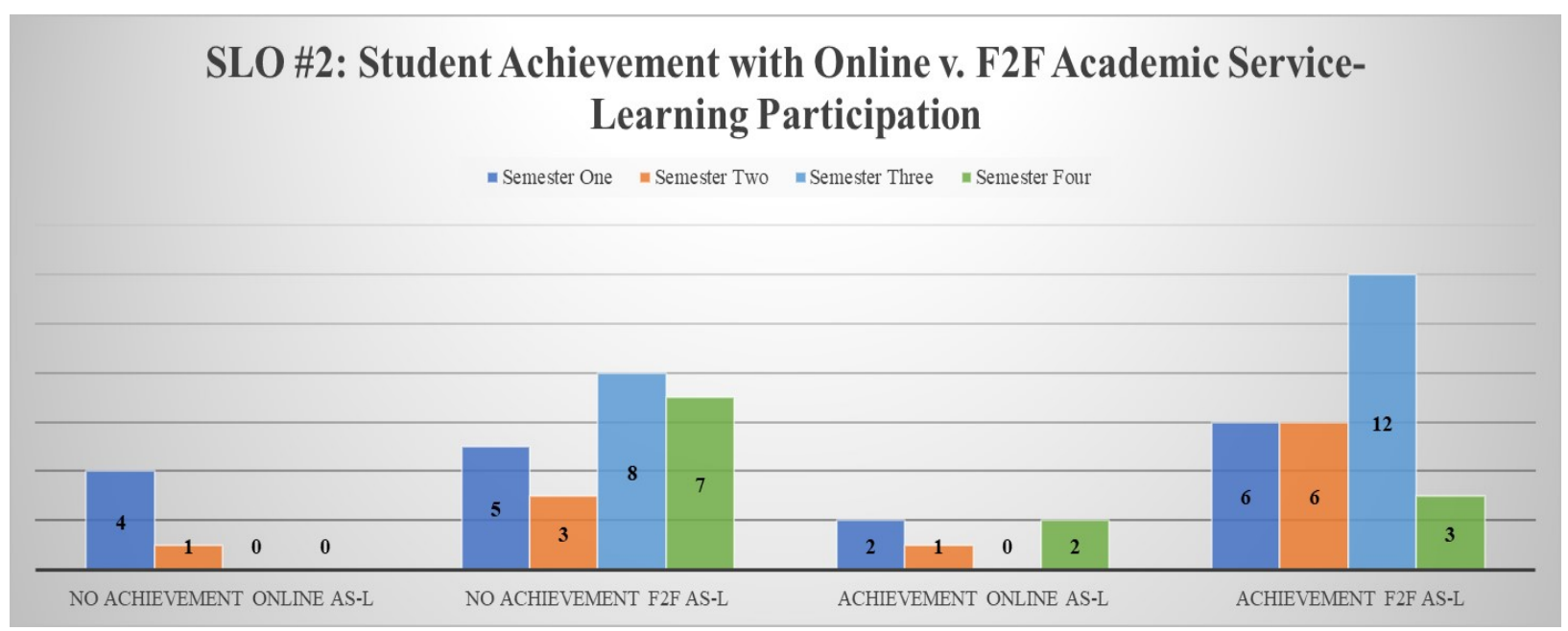

This is what the distribution looks like when the four semesters measured are graphed for the second student learning outcome. Once again, as evidenced by the data displayed in Figure 10, more students demonstrated evidence of achievement of the second learning outcome when participating with an academic service-learning community partner within the F2F learning environment. But is this statistically significant? 
TABLE 8

BIVARIATE REGRESSION ANALYSIS OF STUDENT ACHIEVMENT VERSUS NO

ACHIEVEMENT FOR LEARNING OUTCOME TWO WHEN PARTICIPATING WITH ONLINE VERSUS F2F ACADEMIC SERVICE-LEARNING COMMUNITY PARTNERS

\begin{tabular}{|l|l|r|r|r|r|r|r|}
\hline \multicolumn{8}{|c|}{ Variables in the Equation } \\
\hline & & B & S.E & Wald & df & Sig. & \multicolumn{1}{|c|}{$\operatorname{Exp(B)}$} \\
\hline Step $1^{\text {a }}$ & Nature_Exp & .232 & .691 & .112 & 1 & .737 & 1.261 \\
& Constant & .000 & .632 & .000 & 1 & 1.000 & 1.000 \\
\hline \multicolumn{2}{|l|}{ a. Variable(s) entered on step 1: Nature Exp. } \\
\hline
\end{tabular}

As the data in Table 8 indicates, the odds of demonstrating achievement for the second student learning outcome increases by a factor of 1.261 , or by $26.1 \%$ when participating with an academic service-learning community partner within the F2F learning environment than those who participated with service-learning community partners within the online environment. However, this is not significant as indicated by our $p$ value.

\section{FIGURE 11 \\ DISTRIBUTION OF STUDENT ACHIEVEMENT VERSUS NO ACHIEVEMENT FOR LEARNING OUTCOME FIVE WHEN PARTICIPATING WITH ONLINE VERSUS F2F ACADEMIC SERVICE-LEARNING COMMUNICTY PARTNERS}

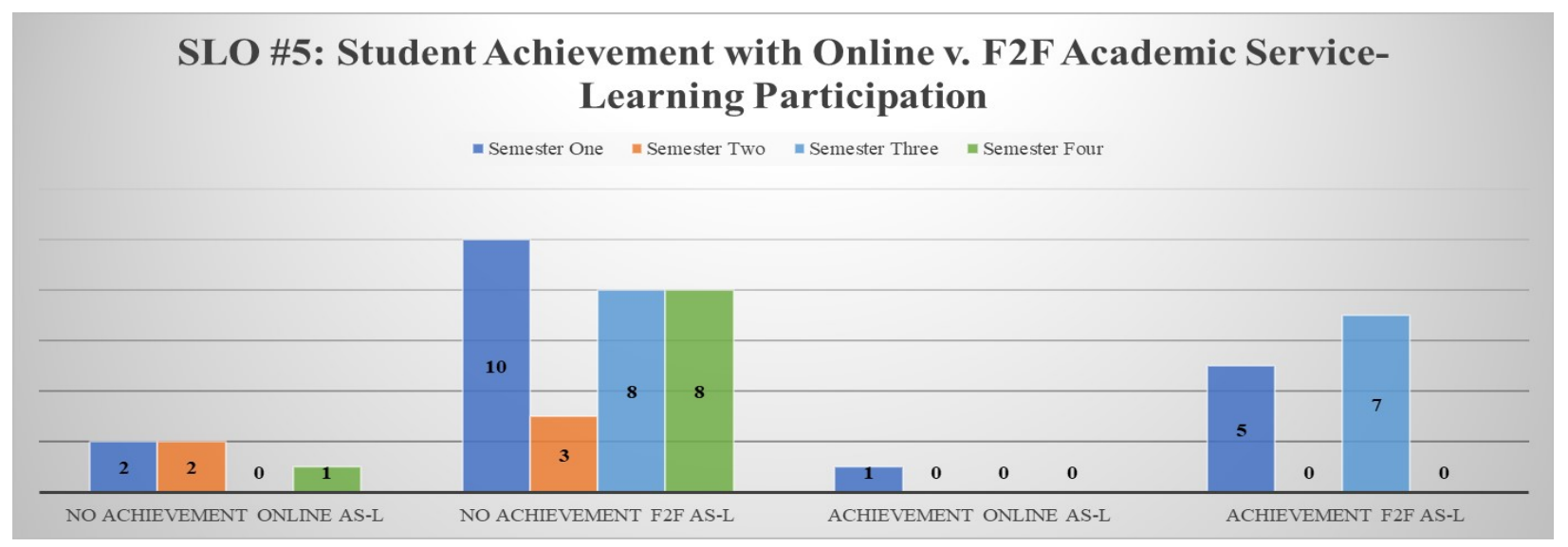

This is what the distribution looks like when the fifth student learning outcome is graphed for the four semesters measured. As evidenced by the data displayed in Figure 11, more students demonstrated achievement in learning outcome five when participating with an academic service-learning community partner within the F2F learning environment than the online learning environment. Let us see if this is statistically significant. 


\section{TABLE 9}

\section{SLO \#5: BIVARIATE REGRESSION ANALYSIS OF STUDENT ACHIEVEMENT V. NO ACHIEVEMENT FOR LEARNING OUTCOME FIVE WHEN PARTICIPATING WITH ONLINE V. F2F ACADEMIC SERVICE-LEARNING COMMUNITY PARTNERS}

\begin{tabular}{|c|c|c|c|c|c|c|c|}
\hline \multicolumn{8}{|c|}{ Variables in the Equation } \\
\hline & & B & S.E & Wald & df & Sig. & $\operatorname{Exp}(B)$ \\
\hline Step $1^{\mathrm{a}}$ & Nature_Exp & .762 & 1.148 & .440 & 1 & .507 & 2.143 \\
\hline & Constant & -1.609 & 1.095 & 2.159 & 1 & .142 & .200 \\
\hline
\end{tabular}

The bivariate regression coefficients in Table 9 reveal that students participating with an academic service-learning community partner within the F2F environment have a greater propensity in successfully demonstrating achievement in learning outcome five than those students who participated in online servicelearning by a factor of 2.143 , or by $114.3 \%$. But once again, because our $p$-value was set at .05 , this is not significantly different.

So overall, students who participated with academic service-learning community partners within the face-to-face learning environment demonstrated slightly higher levels of achievement for learning outcomes one, two, and five than those students who participated in AS-L activities within the online environment. However, it is important to note that these differences are not statistically significant. Therefore, given these results, it seems reasonable to conclude that students completing all forms of academic service-learning had comparable levels of demonstrated achievement as measured by their postreflection assignments.

\section{DISCUSSION}

Results were mixed when determining if student post-reflections demonstrated evidence of achievement between service-learning assessment activities and intended student learning outcomes. While the data for student learning outcome one (SLO1) indicates there was a demonstrated positive effect between student service and student learning it was determined during the construction of the data coding alignment chart (Appendix B) that this learning outcome needed to be broken down into two separate outcomes. This is because two different skill-sets were being measured. The first skill-set asked students to be able to demonstrate how to deal with different types of information resources. The second skill-set measured within this same learning outcome was for students to be able to explain the concepts behind rules and systems employed to provide intellectual access to different media types found within library's, archives, and museums (LAMs). As such, the first research question for SLO1 should ask if the incorporation of academic service-learning activities influenced student achievement in the understanding of how to deal with different types of information resources. This needs to be rewritten and incorporated into the course syllabus as the first indented student learning outcome. The second research question for SLO1 should be reconstructed to ask if the incorporation of academic service-learning activities influenced student achievement in the understanding of concepts behind the rules and systems employed to provide intellectual access to different media types found within library's, archives, and museums (LAMs). This needs to be rewritten in the course syllabus as the second intended student learning outcome. Therefore, while data indicates that the service-learning assessment activity may be properly aligned in demonstrating achievement of the first intended student learning outcome (SLO1), it needs to be rewritten into two separate student learning outcomes. In this way, the faculty researcher can better assess if there is demonstrated evidence between service-learning assessment activities and the intended student learning outcome.

A comparison of data collected for SLO1 and student learning outcome two (SLO2) suggests that student post-reflections will only demonstrate evidence of achievement between service and learning when the assessment activity and learning outcome is tied to the student's service-learning community partner 
and that community partner demonstrates a need for the activity under assessment. This could explain why there was a lack of demonstrated evidence of achievement between student service and student learning in the fourth semester of data collected. That is, there was a lack of need among the community partner's during the fourth semester of classes resulting in a decrease in student post-reflections demonstrating evidence of achievement between service-learning assessment activities and the intended student learning outcome. This is an important point because the needs of the community partner are reciprocated from the classroom to the student and then to the service-learning community partner and back to the classroom. If any of these three components are missing, then the student post-reflections will not demonstrate evidence of achievement between service and learning.

Additional evidence for this interpretation can be gleaned from a qualitative analysis of student postreflections. For example, students from the first, second and third semesters indicated within their postreflection assignments that they understood the theories behind the organization of information and the creation of information access. As such, the academic service-learning projects and assessment activities were directly tied to the first intended student learning outcome. Students also indicated for semesters one, two and three that they were able to meet the second learning outcome (SLO2) by identifying specific tools used at their service-learning community partner site such as Archivist ToolKit and ArchivesSpace. This did not happen during the fourth semester hence the decrease in demonstrated achievement for the first and second student learning outcomes. As such, this is also why the academic service-learning activity did not properly act as the assessment tool in demonstrating student achievement in each of the intended student learning outcomes (SLO1 \& SLO2) during the fourth semester of data measured.

For the third student learning outcome measured, results indicate that the incorporation of academic service-learning activities did not influence student achievement in one's ability to critically analyze the advantages and disadvantages of different types of bibliographic systems. This does not mean that there were no assignments attached to SLO3. There was, and it was a crosswalk assignment from MARC to RDA. However, the students did not state specifically about the advantages or disadvantages of these two systems in connection with their service-learning community partner sites. They simply did the crosswalk assignment. In hindsight, there are two different things that may be happening here. The first is that the faculty member simply provided instructions to students on how to construct the crosswalk assignment. As such, they completed the assignment as instructed. The students were never asked within the crosswalk assignment instructions to critically analyze the advantages and disadvantages of different bibliographic systems as they exist within their community-partner sites. As such, the assessment was either not structured to meet SLO3 or students did not have enough experience within their LIS program to effectively demonstrate achievement of the third student learning outcome.

Qualitative analysis did reveal that when students worked with service-learning community partners for more than one semester that it is possible for one to demonstrate achievement in being able to conduct a comparative analysis on different bibliographic systems. For example, subject \#51 stated how a comparative analysis within the St. John's University Library Catalog with the Center for Migration Studies (CMS) finding aids could be accomplished by looking at the advantages and disadvantages of each. With this prior service-learning experience, this student demonstrated advanced knowledge in working with different bibliographic systems within different information environments. This previous service-learning experience was why the student was able to successfully demonstrate achievement in student learning outcome three. As such, while most students did not possess the skill-sets necessary to conduct a comparative analysis of different bibliographic systems used in different information environments this qualitative evidence is one outlier that needs to be accounted for when (re)constructing student learning outcomes for future classes.

It was also rare to find students who were able to document evidence in their post-reflection assignments in meeting the fourth student learning outcome (SLO4). Upon reviewing results of the fourth learning outcome the faculty researcher reviewed previously constructed academic service-learning assessment activities. This analysis made it apparent that SLO4 should be removed from the LIS 203: Organization of Information course and placed within a more advanced class; perhaps one where this class is a prerequisite such as the LIS 257: Archival Representation course which is also taught by the author of 
this study. In this way, the service-learning assessment activity is not lost - as it is an important skill-set for students to acquire in today's information environment - but integrated into the same type of academic service-learning outcome, crosswalked with the appropriate programmatic goal and, in turn, crosswalked to the corresponding ALA core competency.

Some students were able to demonstrate achievement of the fifth student learning outcome (SLO5) in their post-reflection assignments because they were able to articulate specific examples of what they did while working with their service-learning community partner that made them feel comfortable working within the emerging digital information environment. Some students demonstrated meeting this outcome when they wrote about scanning documents at their service-learning community site by providing access to different types of information objects and how this can encourage lifelong learning. Other students demonstrated evidence in their post-reflections in meeting SLO5 when they spoke about working comfortably within the digital environment and then stating specific reasons as to why this was so, such as creating websites for a historical society and navigating through different software platforms when teaching a student on how to conduct research for journal articles.

In sum, evidence stemming from this constructive alignment study indicates that student postreflections demonstrate evidence of achievement between academic service-learning and achievement of intended student learning outcomes for the first, second and fifth measurements. The first learning outcome needs to be rewritten and broken out into two different learning outcomes. The third student learning outcome needs to be implemented within the LIS 203 course as an assignment that is not tied to an academic service-learning community partner. The fourth learning outcome needs to be removed from the LIS 203: Organization of Information course and placed within a more advanced class such as LIS 257: Archival Representation, which is taught by the same faculty researcher.

Students demonstrated comparable levels of achievement for learning outcomes one, two, and five when working with both online and face-to-face academic service-learning community partners.

\section{LIMITATIONS AND FUTURE RESEARCH}

It is important to note some limitations of this study and the data from which the analysis was conducted. Students were provided with the option to work with a face-to-face or online academic servicelearning community partner. Because of this option to self-select community partners and the nature of academic service-learning projects this resulted in an uneven distribution across groups. In addition, because class sizes were limited, and the associated data collection only took place during a period of five years, the sample size is relatively small which could have skewed results. Despite these limitations, enough data was gathered and analyzed for the faculty researcher to effectively revamp the LIS 203: Organization of Information course alignment chart. Even minor changes to the alignment chart can bring significant results in the form of increased demonstrated achievement of intended student learning outcomes.

Additionally, the faculty researcher will reconstruct the post-reflection assignment so that both qualitative and quantitative student data can be captured within pre-reflection and post-reflection surveys. Implementing a data collection tool that provides information in the form of a pre-reflection survey will allow the faculty researcher to gather information from students regarding what skill-sets they already have upon entering the course and the post-reflection survey will be reconstructed so that the information provided can better determine what skill-sets students are gaining from the course. In this way, a more robust comparative analysis will be possible when the faculty member (re)engages with the curriculumprogram-course alignment process during the next academic semester.

Finally, with the advent of COVID-19 and the resulting institutional shutdown during the 2020-2021 academic semesters, the author of this study was forced to reconceptualize the academic service-learning pedagogy as an online community partner activity. Due to this forced implementation of service-learning within the online environment more data is becoming available to conduct another study in determining if student pre/post-reflection surveys demonstrate evidence of differences in achievement in learning outcomes when participating in online versus onsite academic service-learning assessment activities. 


\section{CONCLUSIONS}

The purpose of this study was to determine if intended student learning outcomes within one online graduate course were aligned with academic service-learning assessment activities as demonstrated by student post-reflection assignments. Five different intended learning outcomes were assessed using 77 student post-reflection assignments during a period of four semesters. Results indicated that the first and second student learning outcomes were aligned with academic service-learning assessment activities. However, while results indicated that the incorporation of service-learning assessment activities had a positive effect in demonstrated student achievement for the first, second, and third semesters measured there was a negative effect during the fourth semester. Data analysis of the fourth semester measured suggests that only if the assessment activity and the learning outcome is tied to the student's service-learning community partner and that community partner demonstrates a need for the activity under assessment then demonstrated student achievement will manifest as evidence in student post-reflection assignments. This is because community partner needs are reciprocated from the classroom to the student and then to the servicelearning community partner and then to service-learning assessment activities. If any of these components are missing, the student post-reflection assignments will not demonstrate evidence of achievement in the first and second student learning outcomes.

There was a misalignment between academic service-learning assessment activities and the third and fourth intended student learning outcomes. This does not mean that assessment activities were not aligned with the third and fourth learning outcomes; they were, but these class assignments were not tied to the student's academic service-learning community partner. Therefore, there was a misalignment between the community partner and the service-learning activity. That is, the incorporation of academic service-learning assessment activities did not influence one's ability to demonstrate achievement in the third and fourth intended student learning outcomes.

The goal of the third learning outcome was for students to be able to critically analyze the advantages and disadvantages of different types of bibliographic systems. It was rare for students to demonstrate evidence of this assessment activity in their post-reflections. For example, student \#51 stated how a comparative analysis between the library catalog from St. John's University could be analyzed against the finding aids housed within the Center for Migration Studies (CMS) Archivist ToolKit program by looking at the advantages and disadvantages of each. However, this student had conducted academic servicelearning assignments and activities in prior classes and as such, was a little more advanced in being able to meet this learning outcome. As such, since most students did not demonstrate achievement in the third learning outcome it seems plausible that an increase in demonstrated achievement among students could be accomplished if this outcome were moved to a more advanced course and taught by the author of this study.

It was also rare for a student to be able to document evidence in their post-reflection assignments in meeting the fourth intended learning outcome. The goal of this student learning outcome was for a student to be able to make their specific community data content standards interoperable across different information environments utilizing different data content standards. As such, since the incorporation of this assignment as an academic service-learning assessment activity did not influence student achievement for this learning outcome, the decision was made by the faculty member to remove this assignment from the LIS 203 course and place it within a more advanced class, such as one that requires LIS 203 as a prerequisite.

For the fifth and final learning outcome results were mixed. The incorporation of academic servicelearning assessment activities had some influence on student achievement for the first and second semesters measured but the results were not strong enough to indicate that there was a positive effect. Some students were able to demonstrate having met learning outcome five in their post-reflection assignments by articulating that they were able to work comfortably within the digital environment and then providing specific examples of activities they engaged in while at their service-learning community partner site. There was no influence between academic service-learning assessment activities and student achievement of learning outcome five for the third and four semesters. 
Finally, students who participated in onsite versus online service-learning projects demonstrated slightly higher levels of achievement, as they had greater odds, or a greater probability, of meeting student learning outcomes one, two, and five. However, it is important to note that this difference is not significantly significant. Moreover, there were some limitations to this analysis and the data. That is, students were not assigned to online and onsite conditions, which resulted in an uneven distribution across groups. In addition, because class sizes were limited, and the fact that only four years of data was used, the sample size is relatively small. Therefore, given the results of this study, it seems reasonable to conclude that students completing all forms of academic service-learning had comparable levels of achievement as measured by their post-reflection assignments.

Results of this data analysis were taken into consideration when reconstructing the LIS 203 alignment chart which can be found in Appendix C. This realignment of intended student learning outcomes and assessment activities required the faculty researcher to reengage with the curriculum-program-course alignment process. Some changes to the LIS 203 alignment chart included altering assignments from a service-learning community partner assessment activity to a simple classroom assignment, the addition of program goals, and the addition of two ALA core competencies. With the impact of COVID-19 and institutional shutdown, academic service-learning is still a required component of the LIS 203 course and is conducted with service-learning community partners within the online environment. As such, more data will be available for a future study in assessing if there is a difference in student achievement of learning outcomes when participating with an online versus an onsite service-learning community partner.

\section{REFERENCES}

Allan, J. (1996). Learning outcomes in higher education. Studies in Higher Education, 21(1), 93-108.

American Library Association. (2008). Searchable database of ALA-accredited programs. Retrieved from $\mathrm{http}: / / \mathrm{www}$.ala.org/educationcareers/accreditedprograms/directory/search

American Library Association Council. (2009). ALA's core competencies of librarianship. American Library Association. Retrieved from

http://www.ala.org/educationcareers/sites/ala.org.educationcareers/files/content/careers/corecomp /corecompetences/finalcorecompstat09.pdf

American Library Association Office for Accreditation (2019). Standards for accreditation of master's programs in library and information studies. Retrieved from

http://www.ala.org/educationcareers/sites/ala.org.educationcareers/files/content/standards/Standar ds_2019_ALACouncil-adopted_01-28-2019.pdf

Angel, C. (2016). Collaboration among faculty members and community partners: Increasing the quality of online library and information science graduate programs through academic service-learning. Journal of Library \& Information Services in Distance Learning, 10(1-2), 4-14. https://www.doi.org/10.1080/1533290X.2016.1240741

Angel, C., \& Robinson, G. (2017). Using ePortfolios to assess student achievement within an online library and information studies program. Journal of Library \& Information Services in Distance Learning, 11(3-4), 330-345. https://doi.org/10.1080/1533290X.2017.1338206

Ball, M.A., \& Schilling, K. (2006). Service learning, technology and LIS education. Journal of Education for Library and Information Science, 47(4), 277-290.

Ball, M. (2008). Practicums and service learning in LIS education. Journal of Education for Library and Information Science, 49(1), 70-82.

Barth, M., Adomßent, M., Fischer, D., Richter, S., \& Rieckmann, M. (2014). Learning to change universities from within: A service-learning perspective on promoting sustainable consumption in higher education. Journal of Cleaner Production, 62, 72-81.

https://doi.org/10.1016/j.jclepro.2013.04.006

Bettencourt, M. (2015). Supporting student learning outcomes through service learning. Foreign Language Annals, 48(3), 473-490. https://www.doi/org/10.1111/flan.12147

Biggs, J. (1996). Enhancing teaching through constructive alignment. Higher Education, 32(3), 347-364. 
Biggs, J.B., \& Tang, C.S. (2011). Teaching for quality learning at university: What the student does (4th ed.). McGraw-Hill: Society for Research into Higher Education \& Open University Press.

Billig, S.H., Root, S., \& Jesse, D. (2005). The relationship between the quality indicators of servicelearning and student outcomes: Testing the professional wisdom. In S. Root, J. Callahan, \& S.H. Billig (Series Eds.), Advances in Service-Learning Research: Vol 5. Improving service-learning practice: Research on models to enhance impacts (pp. 97-115). Information Age Publishing Inc.

Bossaller, J. (2016). Service learning as innovative pedagogy in online learning. Education for Information, 32(1), 35-53.

Bowie, A., \& Cassim, F. (2016). Linking classroom and community: A theoretical alignment of service learning and human-centered design methodology in contemporary communication design education. Education as Change, 1(1), 1-23. https://doi.org/10,17159/1947/2016/556

Bringle, R.G., \& Hatcher, J.A. (1996). Implementing service learning in higher education. The Journal of Higher Education, 67(2), 221-239.

Celio, C., Durlak, J., \& Dymnicki, A. (2011). A meta-analysis of the impact of service-learning on students. The Journal of Experiential Education, 34(2), 164-181. https://www.doi.org/10.1177/105382591103400205

Chardon, T., Pauline, C., Sara, H., \& Caroline, H. (2011). Criterion referenced assessment as a form of feedback: Student and staff perceptions in the initial stages of a new law degree. International Journal of Pedagogies and Learning, 6(3), 232-242. https://doi.org/10.5172/ijpl.2011.6.3.232

Cohen, S. (1987). Instructional alignment: Searching for a magic bullet. Educational Researcher, 16(8), $16-20$.

Conrad, D., \& Hedin, D. (1982). The impact of experiential education on adolescent development. Child and Youth Services. Retrieved from http://digitalcommons.unomaha.edu/slcek12

Council of the American Library Association. (2019). Standards for accreditation of master's programs in library and information studies. Retrieved from http://www.ala.org/educationcareers/sites/ala.org.educationcareers/files/content/standards/Standar ds_2019_ALACouncil-adopted_01-28-2019.pdf

Council for Higher Education Accreditation. (2019a). Clearing issues and granting expansion of the ALA scope of accreditation to the United Kingdom. Retrieved from http://www.ala.org/aboutala/sites/ala.org.aboutala/files/content/accreditation/CHEACoR\%20Action\%20Letter\%20and\%20Scope\%20Change.pdf

Council for Higher Education Accreditation. (2019b). CHEA response to ALA-CoA interim report followup of April 30, 2019. Retrieved from http://www.ala.org/aboutala/offices/accreditation/chearecognition

Dames, G.E. (2012). Enhancing of teaching and learning through constructive alignment. Acta Theologica, 32(2), 35-53.

Dewey, J. (1938). Experience and education. New York, NY: Simon \& Schuster.

Fullerton, A., Reitenauer, V.L., \& Kerrigan, S.M. (2015). A grateful recollecting: A qualitative study of the long-term impact of service-learning on graduates. Journal of Higher Education Outreach and Engagement, 19(2), 65-69. https://openjournals.libs.uga.edu/jheoe/article/view/1194/1192

Fulmer, G., Tanas, J., \& Weiss, K. (2018). The challenges of alignment for the next generation science standards. Journal of Research in Science Teaching, 55(7), 1076-1100. https://www.doi.org/10.1002/tea.21481

Gallagher, C.W. (2012). The trouble with outcomes: Pragmatic inquiry and educational aims. College English, 75(1), 42-60.

Hamilton, S.F., \& Zeldin, R.S. (1987). Learning civics in the community. Curriculum Inquiry, 17(4), $407-420$.

Harland, T. (2003). Vygotsky's Zone of Proximal Development and problem-based learning: Linking a theoretical concept with practice through action research. Teaching in Higher Education, 8(2), 263-272. https://doi.org/10.1080/1356251032000052483 
Hart, S. (2015). Engaging the learner: The ABC's of service-learning. Teaching and Learning in Nursing, 10(2), 76-79. https://doi.org/10.1016/j.teln.2015.01.001

Kolb, D.A. (1984). Experiential learning: Experience as the source of learning and development. Prentice-Hall, Inc.

La Marca, P.M. (2001). Alignment of standards and assessments as an accountability criterion. Practical Assessment, Research \& Evaluation, 7(21).

Martin, F. (2011). Instructional design and the importance of instructional alignment. Community College Journal of Research and Practice, 35(12), 955-972. https://doi.org/10.1080/10668920802466483

Martone, A., \& Sireci, S. (2009). Evaluating alignment between curriculum, assessment, and instruction. Review of Educational Research, 79(4), 1332-1361.

Mills, G.E. (2003). Action research: A guide for the teacher researcher (2nd ed). Merrill Prentice-Hall.

Molee, L.M., Henry, M.E., Sessa, V.I., \& McKinney-Prupis, E.R. (2010). Assessing learning in servicelearning courses through critical reflection. Journal of Experiential Education, 33(3), 239-257. https://doi.org/10.5193/JEE33.3.239

Norris, J. (2006). The issue: The why (and how) of assessing student learning outcomes in college foreign language programs. The Modern Language Journal, 90(4), 576-583.

Pelton, R.P. (2010). Action research for teacher candidates: Using classroom data to enhance instruction. Rowman \& Littlefield Education.

Ruge, G., Tokede, O., \& Tivendale, L. (2019). Implementing constructive alignment in higher education cross-institutional perspectives from Australia. Higher Education Research \& Development, 38(4), 833-848. https://doi.org/10.1080/07294360.2019.1586842

Salam, M., Iskandar, D., Ibrahim, D., \& Farooq, M. (2019). Service learning in higher education: A systematic literature review. Asia Pacific Education Review, 20(4), 573-593. https://doi.org/10.1007/s12564-019-09580-6

Salkind, N.J. (2017). Statistics for People Who (Think They) Hate Statistics (6th ed.). SAGE Publications Inc.

St. John's University. (2020). Division of Library and Information Science: Program goals and outcomes. Retrieved from https://www.stjohns.edu/resources/places/library-and-information-science

Tam, M. (2014). Outcomes-based approach to quality assessment and curriculum improvement in higher education. Quality Assurance in Education, 22(2), 158-168. https://doi.org/10.1108/QAE-092011-0059

Tyler, R.W. (1949). Basic principles of curriculum and instruction. The University of Chicago Press.

Voss, H.C., Mathews, L.R., Fossen, T., Scott, G., \& Schaefer, M. (2015). Community-academic partnerships: Developing a service-learning framework. Journal of Professional Nursing, 31(5), 395-401. https://doi.org/10.1016/j.profnurs.2015.03.008

Webb, N.L. (2002). An analysis of the alignment between mathematic standards and assessments for three states. Paper presented at the annual meeting of the American Educational Research Association; April 1-5, 2002; New Orleans, LA.

Wiggins, G., \& McTighe, J. (2005). Understanding by design (Expanded 2nd ed.). Alexandria, VA: Association for Supervision and Curriculum Development (ASCD).

Yorio, P.L., \& Ye, F. (2012). A meta-analysis on the effects of service-learning on the social, personal, and cognitive outcomes of learning. Academy of Management Learning \& Education, 11(1), 9-9. 


\section{APPENDICES}

\section{APPENDIX A \\ LIS 203 ALIGNMENT CHART BEFORE CONSTRUCTIVE ALIGNMENT STUDY}

\begin{tabular}{|c|c|c|c|}
\hline ALA Core Competency & DLIS Program Goals & Student Learning Outcomes & Assessments \\
\hline $\begin{array}{l}\text { 3. Organization of } \\
\text { Recorded Knowledge } \\
\text { and Information } \\
\text { 3A. The principles } \\
\text { involved and the } \\
\text { developmental, } \\
\text { descriptive, and } \\
\text { evaluative skills needed } \\
\text { in the organization, } \\
\text { representation, and } \\
\text { retrieval of recorded } \\
\text { knowledge and } \\
\text { information resources. }\end{array}$ & $\begin{array}{l}\text { 3A - Understand the } \\
\text { principles involved and } \\
\text { the developmental, } \\
\text { descriptive, and } \\
\text { evaluative skills needed } \\
\text { in the organization, } \\
\text { representation and } \\
\text { retrieval of recorded } \\
\text { knowledge and } \\
\text { information sources. }\end{array}$ & $\begin{array}{l}\# 1 \text { - Upon completion of } \\
\text { this course students will be } \\
\text { able to deal with different } \\
\text { types of information } \\
\text { resources and explain the } \\
\text { concepts behind rules and } \\
\text { systems in order to provide } \\
\text { intellectual access to } \\
\text { different media types found } \\
\text { within library's, archives, } \\
\text { and museums (LAMs). }\end{array}$ & $\begin{array}{l}\text { AS-L } \\
\text { Community } \\
\text { Projects }\end{array}$ \\
\hline $\begin{array}{l}\text { 3B. The developmental, } \\
\text { descriptive \& } \\
\text { evaluative skills needed } \\
\text { to organize recorded } \\
\text { knowledge and } \\
\text { information. }\end{array}$ & $\begin{array}{l}3 \mathrm{~A}-\text { Understand the } \\
\text { principles involved and } \\
\text { the developmental, } \\
\text { descriptive, and } \\
\text { evaluative skills needed } \\
\text { in the organization, } \\
\text { representation and } \\
\text { retrieval of recorded } \\
\text { knowledge and } \\
\text { information sources. }\end{array}$ & $\begin{array}{l}\# 2 \text { - Upon completion of } \\
\text { this course students will be } \\
\text { able provide examples of } \\
\text { standards in data structure, } \\
\text { data content, and data } \\
\text { values. }\end{array}$ & $\begin{array}{l}\text { Descriptive } \\
\text { Cataloging } \\
\text { Assignment } \\
\text { Name \& Subject } \\
\text { Authorities } \\
\text { Assignment }\end{array}$ \\
\hline $\begin{array}{l}\text { 3A. The principles } \\
\text { involved and the } \\
\text { developmental, } \\
\text { descriptive, and } \\
\text { evaluative skills needed } \\
\text { in the organization, } \\
\text { representation, and } \\
\text { retrieval of recorded } \\
\text { knowledge and } \\
\text { information resources. }\end{array}$ & $\begin{array}{l}3 \mathrm{~A}-\text { Understand the } \\
\text { principles involved and } \\
\text { the developmental, } \\
\text { descriptive, and } \\
\text { evaluative skills needed } \\
\text { in the organization, } \\
\text { representation and } \\
\text { retrieval of recorded } \\
\text { knowledge and } \\
\text { information sources. }\end{array}$ & $\begin{array}{l}\# 3 \text { - Upon completion of } \\
\text { this course students will be } \\
\text { able to critically analyze the } \\
\text { advantages and } \\
\text { disadvantages of each type } \\
\text { of bibliographic system } \\
\text { (DACS-Archives; Dublin } \\
\text { Core-Web; RDA-Library; } \\
\text { CCO-Museums). }\end{array}$ & $\begin{array}{l}\text { Comparative } \\
\text { Analysis of } \\
\text { Different Content } \\
\text { Management } \\
\text { Systems used } \\
\text { within Service- } \\
\text { Learning } \\
\text { Community } \\
\text { Partner } \\
\text { Institutions }\end{array}$ \\
\hline $\begin{array}{l}\text { 3C. The systems of } \\
\text { cataloging, metadata, } \\
\text { indexing, and } \\
\text { classification standards } \\
\text { and methods used to } \\
\text { organize recorded } \\
\text { knowledge and } \\
\text { information. }\end{array}$ & $\begin{array}{l}\text { 3B - Demonstrate } \\
\text { ability to organize } \\
\text { recorded knowledge and } \\
\text { information using the } \\
\text { systems of cataloging, } \\
\text { metadata, indexing, and } \\
\text { classification standards } \\
\text { and methods. }\end{array}$ & $\begin{array}{l}\text { \#4 - Upon completion of } \\
\text { this course students will be } \\
\text { able to take their specific } \\
\text { community data content } \\
\text { standards and make them } \\
\text { interoperable across } \\
\text { different information } \\
\text { environments utilizing } \\
\text { different data content } \\
\text { standards. }\end{array}$ & Tagging Project \\
\hline
\end{tabular}




\begin{tabular}{|l|l|l|l|}
\hline 3C. The systems of & 3B - Demonstrate & $\# 5-$ Upon completion of & AS-L Blog Post \\
cataloging, metadata, & ability to organize & this course students will be & \\
indexing, and & recorded knowledge and & able to work comfortably & \\
classification standards & information using the & within the emerging digital & \\
and methods used to & systems of cataloging, & information environment. & \\
organize recorded & metadata, indexing, and & & \\
knowledge and & classification standards & & \\
information. & and methods. & & \\
\hline
\end{tabular}

APPENDIX B

DATA CODING ALIGNMENT CHART

\begin{tabular}{|c|c|c|c|c|}
\hline $\begin{array}{l}\text { ALA Core } \\
\text { Competency } \\
\# 3\end{array}$ & $\begin{array}{l}\text { ALA Sub- } \\
\text { Competency }\end{array}$ & $\begin{array}{l}\text { Student Learning } \\
\text { Outcomes }\end{array}$ & Assessments & Coding Guidelines \\
\hline \multirow[t]{2}{*}{$\begin{array}{l}\text { Organization } \\
\text { of Recorded } \\
\text { Knowledge } \\
\text { and } \\
\text { Information }\end{array}$} & $\begin{array}{l}\text { 3A. The } \\
\text { principles } \\
\text { involved and the } \\
\text { developmental, } \\
\text { descriptive, and } \\
\text { evaluative skills } \\
\text { needed in the } \\
\text { organization, } \\
\text { representation, } \\
\text { and retrieval of } \\
\text { recorded } \\
\text { knowledge and } \\
\text { information } \\
\text { resources. }\end{array}$ & $\begin{array}{l}\text { SLO1: Upon } \\
\text { completion of this } \\
\text { course students will be } \\
\text { able to deal with } \\
\text { different types of } \\
\text { information resources. } \\
\text { SLO1: Upon } \\
\text { completion of this } \\
\text { course students will be } \\
\text { able to explain the } \\
\text { concepts behind rules \& } \\
\text { systems in order to } \\
\text { provide intellectual } \\
\text { access to different } \\
\text { media types found } \\
\text { within Library's } \\
\text { Archives \& Museums } \\
\text { (LAMs). }\end{array}$ & $\begin{array}{l}\text { AS-L } \\
\text { Community } \\
\text { Projects }\end{array}$ & $\begin{array}{l}\text { a-Different types of info. } \\
\text { Resources = } \\
\text { understand/development } \\
\text { of the skills needed to } \\
\text { deal w/ different types } \\
\text { of information. } \\
\text { A change in media type } \\
\text { w/ a change in access = } \\
\text { this counts } \\
\text { If it is just a scanned } \\
\text { document, i.e. "I learned } \\
\text { how to scan" = this does } \\
\text { not count. } \\
\text { b-Explain the concepts } \\
\text { behind rules \& systems } \\
\text { in order to provide } \\
\text { intellectual access to } \\
\text { different media types } \\
\text { found in LAMs }\end{array}$ \\
\hline & $\begin{array}{l}\text { 3B. Demonstrate } \\
\text { ability to } \\
\text { organize } \\
\text { recorded } \\
\text { knowledge and } \\
\text { information using } \\
\text { the systems of } \\
\text { cataloging, } \\
\text { metadata, } \\
\text { indexing, and } \\
\text { classification } \\
\text { standards and } \\
\text { methods. }\end{array}$ & $\begin{array}{l}\text { SLO2: Upon } \\
\text { completion of this } \\
\text { course students will be } \\
\text { able to define \& provide } \\
\text { examples of standards } \\
\text { in data structure, data } \\
\text { content, and data } \\
\text { values. }\end{array}$ & $\begin{array}{l}\text { Descriptive } \\
\text { Cataloging } \\
\text { Assignment } \\
\text { Name \& } \\
\text { Subject } \\
\text { Authorities } \\
\text { Assignment }\end{array}$ & $\begin{array}{l}\text { Data Structure = XML; } \\
\text { HTML } \\
\text { Data Content = DACS; } \\
\text { RDA; MARC; DC } \\
\text { Data Values = LCSH } \\
\text { Provide examples of } \\
\text { systems; does not have } \\
\text { to be more than one }\end{array}$ \\
\hline
\end{tabular}




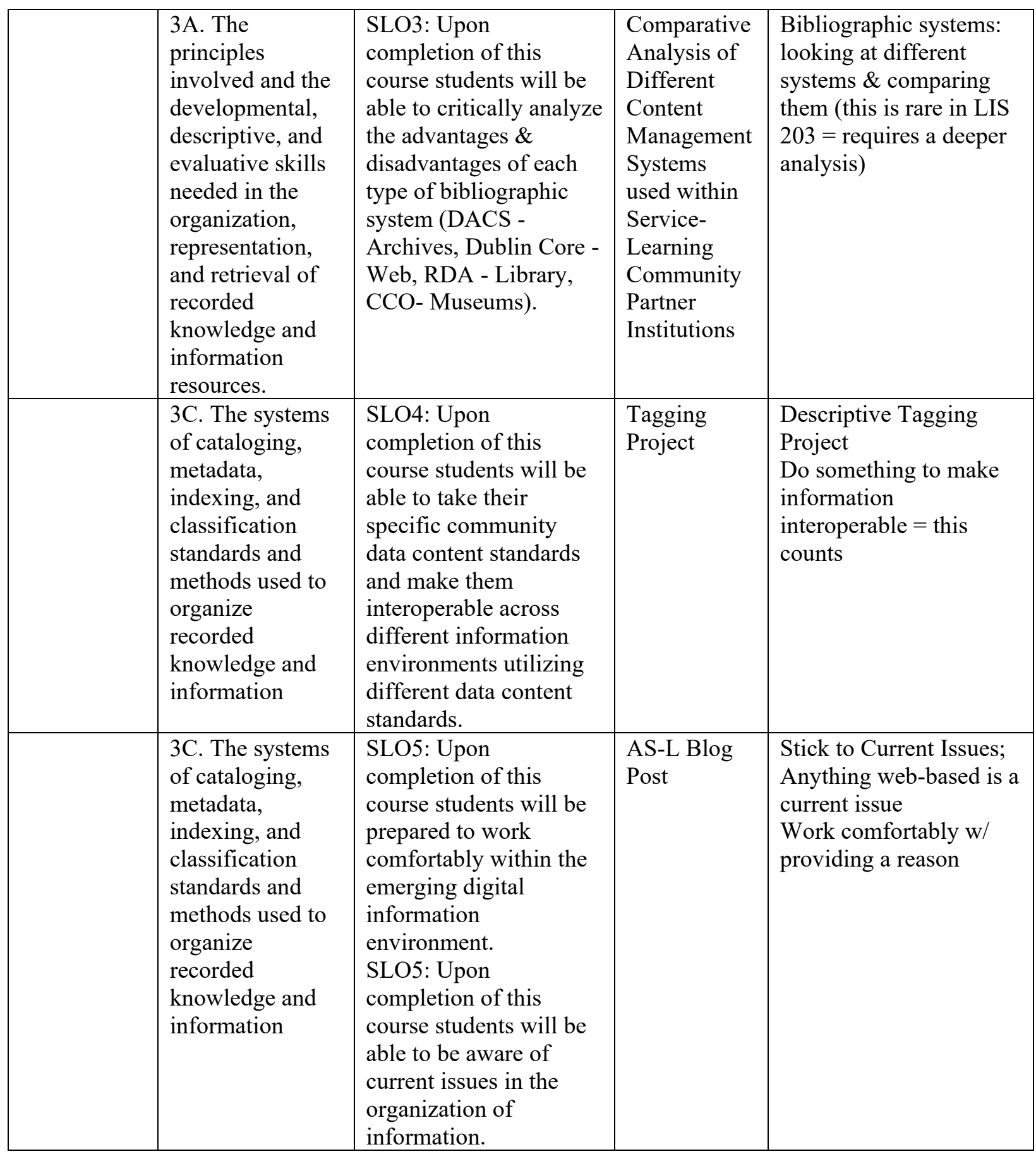




\section{APPENDIX C \\ RECONSTRUCTED LIS 203 ALIGNMENT CHART}

\begin{tabular}{|c|c|c|c|}
\hline ALA Core Competencies & DLIS Program Goals & Student Learning Outcomes & Assessments \\
\hline $\begin{array}{l}\text { 1. Foundations of the } \\
\text { Profession } \\
\text { 1G. The legal framework } \\
\text { within which libraries \& } \\
\text { information agencies } \\
\text { operate. That framework } \\
\text { includes laws relating to } \\
\text { copyright, privacy, freedom } \\
\text { of expression, equal rights } \\
\text { (e.g., the Americans w/ } \\
\text { Disabilities Act), and } \\
\text { intellectual property. }\end{array}$ & $\begin{array}{l}\text { 1B - Demonstrate } \\
\text { knowledge of the ethics, } \\
\text { values, and foundational } \\
\text { principles and the role of } \\
\text { library and information } \\
\text { professionals in the } \\
\text { promotion of democratic } \\
\text { and legal principles and } \\
\text { intellectual freedom. }\end{array}$ & $\begin{array}{l}\# 1 \text { - Upon completion of } \\
\text { this course students will be } \\
\text { able to demonstrate \& } \\
\text { provide an example of the } \\
\text { legal framework within } \\
\text { which libraries \& } \\
\text { information agencies } \\
\text { operate. }\end{array}$ & $\begin{array}{l}\text { Copyright } \\
\text { Assignment } \\
\text { Blog Post } \\
\text { Participation } \\
\text { Consent Form }\end{array}$ \\
\hline $\begin{array}{l}\text { 1I. The techniques used to } \\
\text { analyze complex problems } \\
\text { and create appropriate } \\
\text { solutions. } \\
\text { 1J. Effective } \\
\text { communication techniques } \\
\text { (verbal and written). }\end{array}$ & $\begin{array}{l}\text { 1D - Demonstrate } \\
\text { effective communication } \\
\text { techniques (verbal and } \\
\text { written) used to analyze } \\
\text { complex problems and } \\
\text { create appropriate } \\
\text { solutions. }\end{array}$ & $\begin{array}{l}\# 2 \text { - Upon completion of } \\
\text { this course students will be } \\
\text { able to interface with } \\
\text { information professionals in } \\
\text { order to apply their learning } \\
\text { to an authentic } \\
\text { environment. }\end{array}$ & $\begin{array}{l}\text { AS-L } \\
\text { Activities (i.e. } \\
\text { weeding, } \\
\text { research, } \\
\text { create finding } \\
\text { aid, metadata, } \\
\text { build } \\
\text { websites) } \\
\text { *Specific to } \\
\text { each } \\
\text { individual AS- } \\
\text { L Community } \\
\text { Partner }\end{array}$ \\
\hline $\begin{array}{l}\text { 3. Organization of } \\
\text { Recorded Knowledge and } \\
\text { Information } \\
\text { 3A. The principles involved } \\
\text { and the developmental, } \\
\text { descriptive, and evaluative } \\
\text { skills needed in the } \\
\text { organization, } \\
\text { representation, and retrieval } \\
\text { of recorded knowledge and } \\
\text { information resources. }\end{array}$ & $\begin{array}{l}\text { 3A - Understand the } \\
\text { principles involved and } \\
\text { the developmental, } \\
\text { descriptive, and } \\
\text { evaluative skills needed } \\
\text { in the organization, } \\
\text { representation and } \\
\text { retrieval of recorded } \\
\text { knowledge and } \\
\text { information resources. }\end{array}$ & $\begin{array}{l}\# 3 \text { - Upon completion of } \\
\text { this course students will be } \\
\text { able to explain the concepts } \\
\text { behind rules and systems in } \\
\text { order to provide intellectual } \\
\text { access to different media } \\
\text { types found in LAMs. }\end{array}$ & $\begin{array}{l}\text { Research \& } \\
\text { Write Draft } \\
\text { Blog Post } \\
\text { AS-L Blog }\end{array}$ \\
\hline $\begin{array}{l}\text { 3B. The developmental, } \\
\text { descriptive \& evaluative } \\
\text { skills needed to organize } \\
\text { recorded knowledge and } \\
\text { information } \\
\text { 3C. The systems of } \\
\text { cataloging, metadata, } \\
\text { indexing, and classification } \\
\text { standards and methods used }\end{array}$ & & $\begin{array}{l}\text { \#4 - Upon completion of } \\
\text { this course students will be } \\
\text { able to critically analyze the } \\
\text { advantages \& } \\
\text { disadvantages of each type } \\
\text { of data content standard } \\
\text { (DACS - Archives, Dublin } \\
\text { Core - Web, RDA - } \\
\text { Library, CCO- Museums). }\end{array}$ & $\begin{array}{l}\text { AS-L Blog } \\
\text { Descriptive } \\
\text { Cataloging } \\
\text { Assignment } \\
\text { (metadata) } \\
\text { Tagging } \\
\text { Assignment }\end{array}$ \\
\hline
\end{tabular}




\begin{tabular}{|c|c|c|c|}
\hline $\begin{array}{l}\text { to organize recorded } \\
\text { knowledge and information }\end{array}$ & & & \\
\hline $\begin{array}{l}\text { 3C. The systems of } \\
\text { cataloging, metadata, } \\
\text { indexing, and classification } \\
\text { standards and methods used } \\
\text { to organize recorded } \\
\text { knowledge and information }\end{array}$ & $\begin{array}{l}\text { 3B - Demonstrate ability } \\
\text { to organize recorded } \\
\text { knowledge and } \\
\text { information using the } \\
\text { systems of cataloging, } \\
\text { metadata, indexing, and } \\
\text { classification standards } \\
\text { and methods. }\end{array}$ & $\begin{array}{l}\# 5 \text { - Upon completion of } \\
\text { this course students will be } \\
\text { able to define and provide } \\
\text { examples of standards in } \\
\text { data structure, data content, } \\
\text { and data values. This } \\
\text { includes an elementary } \\
\text { understanding of the major } \\
\text { systems of cataloging, } \\
\text { metadata, indexing \& } \\
\text { classification standards and } \\
\text { methods used to organize } \\
\text { recorded knowledge \& } \\
\text { information. }\end{array}$ & $\begin{array}{l}\text { Metadata } \\
\text { Assignment } \\
\text { Tagging } \\
\text { Assignment }\end{array}$ \\
\hline $\begin{array}{l}\text { 4. Technological } \\
\text { Knowledge and Skills } \\
\text { 4A. Information, } \\
\text { communication, assistive, } \\
\text { and related technologies as } \\
\text { they affect the resources, } \\
\text { service delivery, and uses } \\
\text { of libraries and other } \\
\text { information agencies. } \\
\text { 4B. The application of } \\
\text { information, } \\
\text { communication, assistive, } \\
\text { and related technology and } \\
\text { tools consistent with } \\
\text { professional ethics and } \\
\text { prevailing service norms } \\
\text { and applications. }\end{array}$ & $\begin{array}{l}\text { 4A - Acquire, apply, } \\
\text { analyze and assess } \\
\text { information, } \\
\text { communication, } \\
\text { assistive, and other } \\
\text { technological skills } \\
\text { related to resources, } \\
\text { service delivery, } \\
\text { professionalism, } \\
\text { efficacy, and cost- } \\
\text { efficiency of current } \\
\text { technologies and } \\
\text { relevant technological } \\
\text { improvements. }\end{array}$ & $\begin{array}{l}\text { \#6 - Upon completion of } \\
\text { this course students will be } \\
\text { able to demonstrate their } \\
\text { ability to utilize Web } 2.0 \\
\text { technologies in order to } \\
\text { create their AS-L HHC } \\
\text { blog project }\end{array}$ & $\begin{array}{l}\text { Upload Draft } \\
\text { Blog Post to } \\
\text { HHC Website }\end{array}$ \\
\hline
\end{tabular}

